\title{
Questioning Ecosystem Assessment and Restoration Practices in a Major Urban Estuary: Perpetuating Myths of Degradation in Spite of the Facts
}

\author{
John T. Tanacredi ${ }^{1,2}$, Martin P. Schreibman ${ }^{3}$ and Kevin McDonnell ${ }^{4}$ \\ 1. Department of Biology, Chemistry and Environmental Studies, Molloy College, Rockville Center, N.Y. 11570, USA \\ 2. Center for Environmental Research Coastal Oceans Monitoring (CERCOM), Molloy College, Rockville Center, N.Y. 11570, USA \\ 3. Biology Department, Brooklyn College, CUNY, Brooklyn N.Y. 11210, USA \\ 4. Department of Mathematics and Computer Science, Dowling College, Oakdale N.Y. 11769, USA
}

\begin{abstract}
The Jamaica Bay ecosystem is a dichotomy. It encompasses more than 12,000 acres of coastal estuarine marshes and an ecological diversity rivaling any coastal environment in the world. It is considerably altered, and is affected by a variety of ecological insults directly related to the fact that more than 14 million people live in its vicinity. Environmental protection institutions responded to the challenge of protecting the bay, surrounding wetlands and recreational benefits by addressing the increasing load of contaminants into the ecosystem. Billions of dollars have been spent during the past five decades on restoration attempts, including upgrading wastewater treatment plantsand the closure of three major sanitary landfills. Even with the curtailment of untreated wastewater release and ending periodic dredging and filling programs, all activities that are necessary processes in maintaining an urban harbor, the Jamaica Bay ecosystem has reached a point where many believe it to be unrecoverable, requiring massive infusions of restoration dollars. This categorization has been perpetuated based on questionable data (the "myths") that, when investigated in rigorous scientific detail, prove to be unsubstantiated. In this paper, the origin of these myths and the scientific investigation that dispel them are discussed.
\end{abstract}

Key words: Ecosystem based management, eco-restoration, urban ecology, estuaries, ecological health.

\section{Introduction}

Management of Jamaica Bay's natural resources were transferred from the city of New York to the Federal Government in 1972, initiating the creation of the Nation's first urban National Park Service (NPS) unit- the Gateway National Recreation Area (GNRA), encompassing 26,000 acres of uplands and coastal estuarine environments [1]. The NPS management mandate is to preserve the scenic beauty, flora and fauna and recreational opportunities of the estuaries and beaches in the NYC metropolitan area [2-4].

GNRA accommodates tens of millions of visitors every year who enjoy a variety of natural amenities.

Corresponding author: John T. Tanacredi, Ph.D., main research fields: conservation biology, ecotoxicology and estuarine ecology.
Situated along North America's Atlantic coastline, Jamaica Bay is a significant migratory bird habitat and important component of the Atlantic flyway. Numerous aquatic animals, shorebirds and terrestrial coastal plants and animals inhabit this ecosystem, including endangered and threatened species. Preservation of remnant portions of this ecosystem and the restoration of portions that have been disturbed can potentially perpetuate the estuarine habitats and their associated wildlife in and around the Hudson-Raritan river estuary for future generations to enjoy [5-8].

To this end, the New York district of the U.S. Army Corps of Engineers (ACE-NYD), through its National Restoration Initiative for Coastal Ecosystems, provided GNRA funding to support the NPS 
conducting a detailed inventory and biogeochemical characterization of the bay and its environs. The study discussed here is the result of the most detailed ecological investigation accomplished since 1969, when the Port Authority of New York requested the environmental studies board (a joint board of the National Academy of Sciences (NAS) and the National Academy of Engineering) to undertake an evaluation of the environmental impact of extending the runways at the John F. Kennedy (JFK) International Airport. Until this study, the 1969 NAS assessment was the primary reference baseline investigation and inventory for all subsequent studies of Jamaica Bay's natural resources [2-4, 9, 10]. This non-peer reviewed report has been, in large measure, the origin of the myths discussed here. These topics of questionable validity relate to degraded intertidal saltmarsh, tidal flushing times of Jamaica Bay, landfill contamination levels, sub-aqueous borrow pit biological productivity, airport operations and endangered species protection.

The original 1972 legislation creating GNRA identified the NPS as the "owner" of the Jamaica Bay bottomlands and required active participation in subsequent planning efforts and studies such as the New York/New Jersey Harbor Estuary Program (NY/NJ-HEP) under U.S. Environmental Protection Agency (EPA) coordination. The NY/NJ-HEP program identified 45 locations in 1990 within the boundaries of GNRA for which existing data collection, monitoring and inventory work were proposed to be used to develop site-specific restoration plans for Jamaica Bay.

In 1999, the National Park Service GNRA prepared a Site Assessment/Inventory Protocol Manual [11] that outlined the environmental, biological and ecological data sets that should be collected by NPS GNRA. The JABERRT report was the product of the recommendations provided by the Jamaica Bay Blue Ribbon Panel Final Report, originally requested by former New York Congressman A. Weiner [12]. In cooperation with the Aquatic Research and Environmental Assessment Center (AREAC) at Brooklyn College CUNY, the NPS and GNRA formed the JABERRT. JABERRT was comprised of 28 research scientists from 12 non-governmental research organizations and academic institutions, itinitiated the most comprehensive scientific study of the entire Jamaica Bay ecosystem within NPS boundaries over a 1.5-year period (Table 1 and Fig. 1).

The primary objectives of the JABERRT project were to:

- Utilize an easily repeatable, consistent and cost-effective census or inventory methodology, derived from the 12-month sampling regime, which NPS could use for monitoring and to serve as a template to study and evaluate other urban estuaries;

- Provide comprehensive information on the relative abundance and biological diversity of species throughout the entire Jamaica Bay ecosystem with additional special emphasis on 12 priority restoration sites;

- Establish restoration sites based on the idea that the sites were considerably "altered," or that previous eco-types were replaced (i.e., land filled) with "less productive" ecosystem habitat types;

- Recommend sites for restoration that could be maintained by natural processes such as tides, currents, etc., and thus be "maintenance free";

- Utilize the JABERRT report to supplement and enhance pre-existing data and research conducted in Jamaica Bay with existing datasets available since the 1969 NAS study and earlier, based on data retrieval dating back to 1899 (i.e., data obtained from navigational charts);

- Inventory all priority sites (if applicable) each month for at least one year to record seasonal variations;

- Establish a library of materials to include originals of all referenced material for each scientific discipline identified in the JABERRT. The protocols would be housed in a master library of research 
documents about Jamaica Bay by NPS at Gateway NRA for future reference and research needs.

To date, no comprehensive, long-term scientific and/or natural resource inventory or routine monitoring network based on JABERRT results, recommendations or datasets has been implemented. This would greatly assist in establishing the vital signs to determine the future health of the natural resources of Jamaica Bay. Unfortunately, based on activities and action plans since 2003, when the JABERRT report was released to the funding agencies (NPS and ACE-NYD), the majority of recommendations generated by JABERRT essentially have been ignored. The authors believe that the JABERRT data can provide a new and important foundation for decision making regarding future ecosystem management.
The areas of contradiction (the myths), as exhibited here when comparing the older non-peer reviewed reports with the JABERRT studies, include:

(1) Saltmarsh loss and habitat instability are primarily due to sea level rise and dredging, especially Grassy Bay;

(2) Jamaica Bay has a 30-day residence time for tidal flushing of bay waters;

(3) Subaqueous borrow pits need to be filled or "re-contoured";

(4) Landfills have not impacted sediments;

(5) General "health" of the bay is "degraded" due to sewage discharges;

(6) Fisheries and shellfisheries are not productive;

(7) Water quality is degraded;

(8) General eco-health of Jamaica Bay is poor.

Table 1 JABERRT final report Vol. I-III members, their affiliations and specific topics of study [5].

\begin{tabular}{|l|l|l|}
\hline Investigators & Affiliation/participants & Research topics \\
\hline Dr. John T. Tanacredi, PI ${ }^{1,}$ & $\begin{array}{l}\text { Chief Division Natural Resources } \\
\text { NPS-GNRA }\end{array}$ & PI JABERRT NPS-GNRA \\
\hline Dr. Martin Schreibman, Co-PI & Director AREAC Co-PI JABERRT & Administrative oversight (Fisheries Report) \\
\hline Christine Kurtzke & NPS & Finfish inventory \\
\hline Dr. David Franz and Dr. Betty Borowsky & Biology Dept., Brooklyn College, CUNY & Invertebrates (AREAC) \\
\hline Dr. Chris Boyko & AMNH & Invertebrate taxonomy \\
\hline Dr. Mark Botton and Dr. Robert Loveland & $\begin{array}{l}\text { Fordham University and Rutgers } \\
\text { University }\end{array}$ & Horseshoe crabs \\
\hline Don Riepe & NPS, American Littoral Society & Butterflies and insects \\
\hline Dr. James Quinn & URI-GSO & Contaminants in sediments and soil \\
\hline Dr. Jim Allen* & USGS & Hydrodynamics/Geomorphology \\
\hline Dr. Arnold Gordon and associates ${ }^{2}$ & Columbia University-LDEO & $\begin{array}{l}\text { Hydrogeology, paleo, physical } \\
\text { oceanography }\end{array}$ \\
\hline Dr. R. Veit & College of Staten Island CUNY & Birds \\
\hline Dr. Russel Burke & Hofstra University & Herpeto/fauna and mammals \\
\hline Dr. George Frame & DNR, NPS-GNRA & Herpeto/fauna and mammals \\
\hline Dr. Dick Stalter & St. John's University & Vegetation site characterization \\
\hline Dr. Michael Byer* & DNR, NPS-GNRA & Vegetation site characterization \\
\hline $\begin{array}{l}\text { Al McCullough } \\
\text { Environmental Concerns, Inc. }\end{array}$ & $\begin{array}{l}\text { Consultant } \\
\text { Draft EA preparations (Cof E format) }\end{array}$ & $\begin{array}{l}\text { Restoration site conceptual designs } \\
\text { overviews 12 site preliminary designs }\end{array}$ \\
\hline Dr. Mark Ringenary & DNR, NPS-GNRA & Water quality parameters \\
\hline
\end{tabular}

**_-Deceased, 1-Presently Executive Director of CERCOM, Molloy College and 2-Listed in the acknowledgements section. NPS-GNRA $=$ National Park Service-Gateway National Recreation Area, AREAC $=$ Aquatic Research and Environmental Assessment Center, CUNY = City University of New York, AMNH = American Museum of Natural History, URI-GSO = University of Rhode Island Graduate School of Oceanography, USGS = U.S. Geological Survey, DNR = Division of Natural Resources, EA = Environmental Assessment, $\mathrm{C}$ of $\mathrm{E}=$ Corps of Engineers and LDEO = Lamont-Doherty Earth Observatory. 


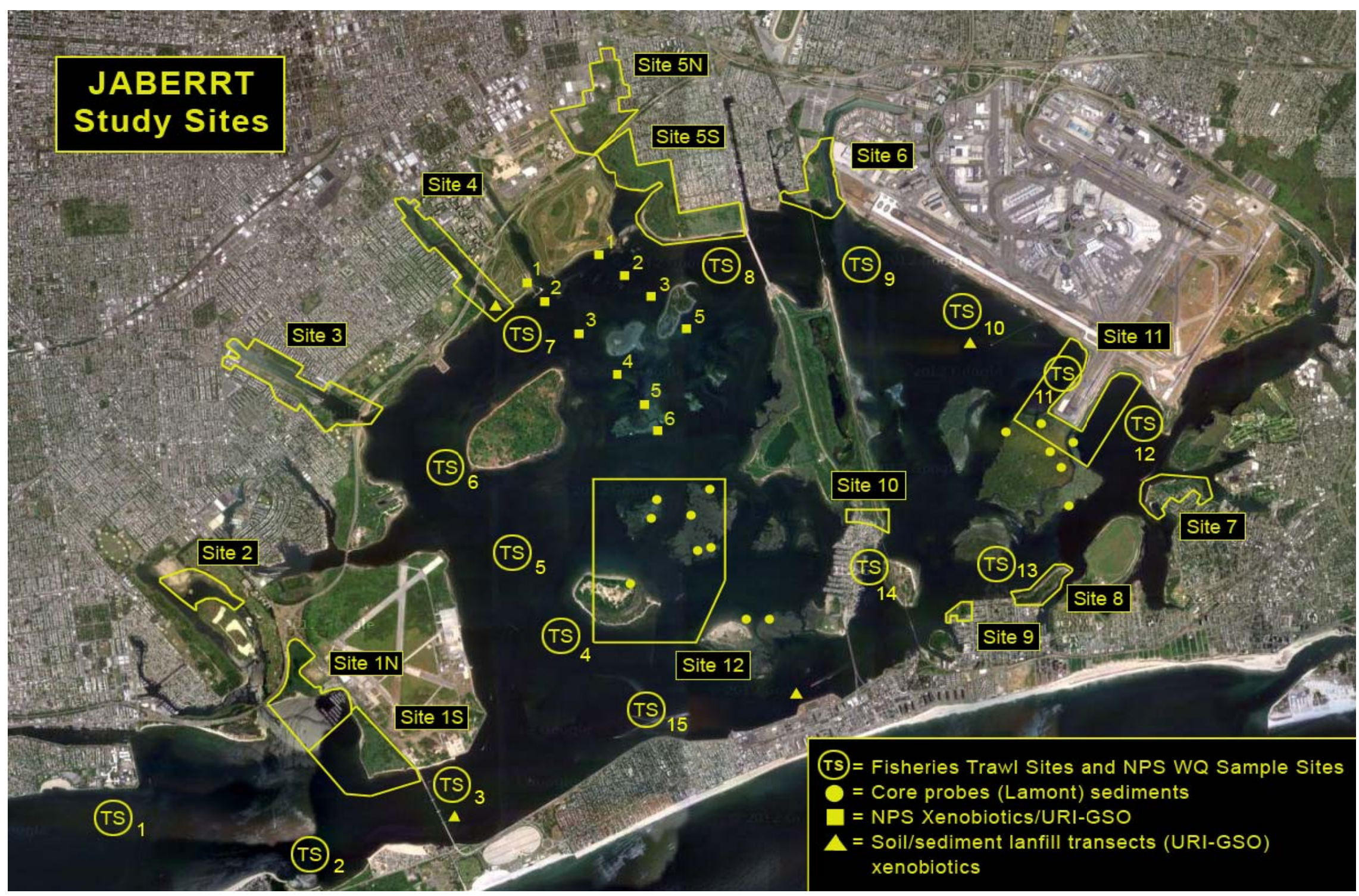

Fig. 1 Field sites sampled by JABERRT from 1999 to 2001 for fisheries species (fisheries trawl sites), macro invertebrates (core probes), water column nutrients (nutrients) and sediment contaminants (landfill transects), URI-GSO = University of Rhode Island Graduate School of Oceanography. 


\section{Material and Methods}

Sampling and analytical protocols were established and employed by each of the scientific team leaders (Table 1).

\subsection{Hydrodynamics, Geophysical Profile and Paleo Botanical Studies}

Sonar and side scan of the sediment morphology of the Jamaica bay floor were used to acquire a suite of high-resolution geophysics of sediment types, high-resolution bathymetry to define the channels for water flux, and "chirp" sub-bottom profiling to define the thickness and age of Jamaica Bay sediments [5, 13]. The examination of sediment cores from transects within the waterways and marshes for environmental changes through time in Jamaica Bay included rate of sea level rise, carbon accumulation rates, local vegetation changes, fire history, climatic changes and anthropogenic influence. Sediment cores were dated by $\mathrm{Pb}-210$ and $\mathrm{Cs}-136$. The flow of water and bottom pressure (sea level) within rockaway inlet was monitored using a current meter and conductivity, temperature and depth sensors at a monitoring station on the marine park bridge. To detect the evolution of a series of deployed fluorescein dye fields in situ (to a concentration of 1 part per $10^{11}$ by weight), Lamont-Doherty Earth Observatory (LDEO) used a Chelsea, Ltd. Aquatracka III fluorometer [13].

\subsection{Microbenthic Invertebrates}

At each site, a specific sampling stratum for estuarine invertebrate fauna was established near Mean Low Water (MLW) with a core sampler that was $26 \mathrm{~cm}$ long with a diameter of $17.5 \mathrm{~cm}$. The samples were all fixed with neutral formalin. Samples consisted of three pooled cores, each with a diameter of $2.9 \mathrm{~cm}$, giving a core area of $6.6 \mathrm{~cm}^{2}$ per core and a total sample area of about $20 \mathrm{~cm}^{2}$. At epibenthic and salt marsh edge stations, copepods were identified to the lowest appropriate taxon (species, when possible). Invertebrates that might not be found within the sediment cores were collected in two transects. As part of this process, stones and shells were dipped into a container of seawater to collect active animals, such as crabs and amphipods [5, 14].

Invertebrates from the salt marsh were taken by a single slice of turf about $10 \mathrm{~cm} \times 60 \mathrm{~cm}$ containing living Spartina alterniflora culms. Ribbed mussels were cut by spade from the marsh edge. In the laboratory, mussels and marsh grass culms were separated under running water. Invertebrates were collected by filtering the material washed from the mussels and Spartina alterniflora culms through a 1 $\mathrm{mm}$ mesh sieve. Data analysis included species richness, estimated using a species diversity index, Shannon-Weiner function. This was calculated for each sampling station and each collection date, providing a diversity index that applies to the total of all species from all replicates combined for the station and date [15]. The Shannon-Weiner diversity function is:

$$
\begin{gathered}
S=\text { Sample values } \\
H^{\prime}=\sum\left(\mathrm{p}_{1}\right)\left(\log _{2} \cdot \mathrm{p}_{1}\right) \\
I=1
\end{gathered}
$$

Where, $\mathrm{H}^{\prime}=$ information content of a sample (bits/individual) $=$ diversity index, $\mathrm{S}=\mathrm{N}=$ number of species and $\mathrm{p}_{1}=$ proportion of total sample belonging to the 1 th species.

\subsection{Fisheries}

The New York State Department of Environmental Conservation (NYSDEC) identified Jamaica Bay as an essential fish habitat for winter flounder, striped bass and blue fish [16]. The finfish survey portion of JABERRT included: (a) beach seining with a $50 \mathrm{ft}$. $\times 4 \mathrm{ft}$. beach seine net; (b) boat trawling with an otter trawl (25 ft. trawl net) towed for $5 \mathrm{~min}$ into the tidal current and (c) gill netting with $100 \mathrm{ft}$. long nets (Fig. 1).

\subsection{Avifauna}

The protocol used for the bird inventory with special emphasis on neotropical migrants involved 
surveys on foot using binoculars and telescopes. Basic data on abundance and species diversity built on data provided by an already established bird banding station at Fort Tilden GNRA (Fig. 1). Banding operations provided critical information on weight gain and the diet of neotropical migrant birds. On each site visit, the abundance of all bird species present was noted, and the area's most often used by birds for feeding, roosting or other activities $[5,17]$.

\subsection{Environmental Contaminants}

Poner sediment samples were taken at the interior bay sites, and all infauna macroinvertebrates were identified to larval stage. All sediment samples were analyzed for selected xenobiotics, including Organochlorine Pesticides (OCPs), Polychlorinated Biphenyls (PCBs), Polycyclic Aromatic Hydrocarbons (PAHs), total metals, Acid Volatile Sulfide (AVS)/Simultaneously Extracted Metals (SEM), Total sediment Organic Carbon (TOC) and sediment grain size distribution (Table 1 and Fig. 1).

\subsection{Vegetation}

Floral surveys were conducted to determine plant cover and habitat diversity. Aerial photographs of each restoration site taken by NYSDEC in 1994 were used to evaluate cover type. Sharp breaks visible on the photographs were located and corroborated in the field. Mappable physiognomic vegetation units (i.e. tall grassland) were emphasized rather than rigorously definable plant communities [18-20].

Vegetation sampling was conducted via the point-centered quarter method combined with percent cover estimates, which were used to characterize each vegetation unit (plants sampled at points along a series of transects). Three vegetation strata were defined:

- Trees, i.e. any woody plant over $2 \mathrm{~m}$ high;

- Shrubs, i.e. any other woody plant, including woody vines (such as Parthenocissus quinquefolia and Celastrus orbiculatus);

- Herbs, i.e. all herbaceous plants including herbaceous vine (such as Solanum dulcarmara and Convolvulus spp.).

Overall percent cover for each species occurring in the samples was calculated. Coverage characteristics included general physiognomy (i.e. woodland, grassland, scrubland and total proportion of ground surface covered by vegetation), other abundant and/or characteristic species that do not appear in the samples due to accidents of sampling or patchiness, habitat criteria (i.e. drainage, soil), successional stage (i.e. pioneer, climax), other ecologically relevant traits (i.e. disturbance, fire) and variability within the unit (i.e. islands of unusual or atypical vegetation).

\subsection{Water Quality}

Water quality has long been identified as a primary "environmental health" indicator for estuarine environments [21]. Each day, four major NYC wastewater treatment plants discharge an average of 320 million gallons of treated wastewater into Jamaica Bay. Since 1976, NPS-GNRA has monitored the quality of water systems within recreational area boundaries for "contact recreational uses" such as fishing and swimming. This effort is mandated by the Federal Clean Water Act of 1972 Amendments.

Water Quality (WQ) sampling locations were determined based on known ecosystem influences, historical data collection sites and general conditions in the area (Fig. 1). Survey methods were taken from Standard Methods for Water and Wastewater (45th Edition) [22]. Parameters included tidal conditions, temperature, turbidity, water depth (at time of sampling, where applicable), turbidity (Secchi disk), $\mathrm{pH}$, nitrite/nitrate, Total Dissolved Nitrogen (TDN), phosphates (total dissolved/Ortho), salinity, conductivity, Dissolved Oxygen (surface and bottom water DO), chlorophyll-a and bacteriological parameters (i.e. total and fecal coliform counts).

All JABERRT water quality data supplemented EPA Storage and Retrieval (STORET) data sets, which include WQ testing by New York City 
Department of Environmental Protection (NYCDEP), NYSDEC and NPS for the previous 30 years. The NPS-GNRA data set included in STORET was at that time the largest individual NPS unit routinely-collected monitoring data set in the NPS system [23].

\subsection{Megafauna}

Mammal, reptile and amphibian population surveys involved several sampling methods including: (a) straight-line transects; (b) walk-about(s); (c) driving on roads; (d) pitfall traps along driftwood fences; (e) cover boards; (f) vocalizations; (g) cage live traps and (h) scent stations [24].

\subsection{Lepidoptera}

The protocol for the Lepidoptera inventory required weekly surveys of all JABERRT sites. The sites were walked, and all butterflies and moths were netted. Specimens were identified and immediately released. All beetles were recorded as other invertebrate species were found at sample locations.

\section{Results}

Results presented here were compiled and assimilated from the original government final JABERRT report [5], submitted by the NPS and coordinated members scientific investigators as part of the JABERRT Team (Table 1).

\subsection{Hydrodynamics and Physical Parameters}

\subsubsection{Geophysical and Hydraulics}

A geophysical survey enabled the major sedimentological terrains within Jamaica Bay to be defined. In the proximity of the marine park bridge and the tidal entrance to Jamaica Bay, large-scale sediment waves were observed [13]. As noted by Gordon, A. L. et al., Tanacredi, J. T., and Schreibman, M. [5, 13], fine grained sediments cover the seafloor throughout most of the region were surveyed. In contrast, data from the main channels through the bay may reflect shallowly buried course grain material or the presence of methane gas. "Grassy Bay was a low backscatter region in both the $100 \mathrm{kHz}$ and $384 \mathrm{kHz}$ data, consistent with the presence of a thicker section of fine-grained sediment than elsewhere within the bay" [13]. It is well documented that the sand borrow pit site in Grassy Bay has sediment of fine particulates $[25,26]$. Borrow pits in Jamaica Bay are a food resource for benthic finfish species, specifically winter flounder (Pleuronectes americanus), a fact supported by photographic documentation of amphipod tubules [26]. These subaqueous sand borrow areas have been intensively scrutinized for potential receipt of contaminated dredged spoils by the US ACE, the Port Authority and NYSDEC in recent years.

Gordon, A. L. [13] revealed that dye injected at a depth of $10 \mathrm{~m}$ has a greater residence time than the dye injected at mid-depth. Lateral diffusivity is approximately $10 \mathrm{~m}^{2} \cdot \mathrm{s}^{-1}$, and vertical diffusivity is approximately $3 \times 10^{-5} \mathrm{~m}^{2} \cdot \mathrm{s}^{-1}$ in the interior where stratification has a Brunt-Vaisala period of 1-4 min.

There was evidence of shear during the ebb flow in Winhole Channel near Grassy Bay. The outflow from Grassy Bay was predominately in the upper half of the water column. The lower half of the water column showed characteristics found in the western section of Jamaica Bay. The vertical mixing of this water prior to the next flood tide affects water exchange with Grassy Bay and reduces the flushing time (Fig. 2) [13].

\subsubsection{Paleo Botanical Profile}

The paleo-environmental history of Jamaica Bay marshes revealed through sampling that the composition of the core changed early in the development of the marsh. Two point five $\mathrm{m}$ in depth and from $246 \mathrm{~cm}$ to $200 \mathrm{~cm}$ the core appeared higher in sand content. Clay reappeared at $2 \mathrm{~m}$ up to $1.9 \mathrm{~m}$, where the core gradually increased in peat content. The upper $1.9 \mathrm{~m}$ consisted mainly of sandy and clayey peat [13].

It was noted by Peteet, D. [13] that there appeared to be a major change in the marsh at a depth of approximately $2 \mathrm{~m}$. Sedge did not appear in the core 


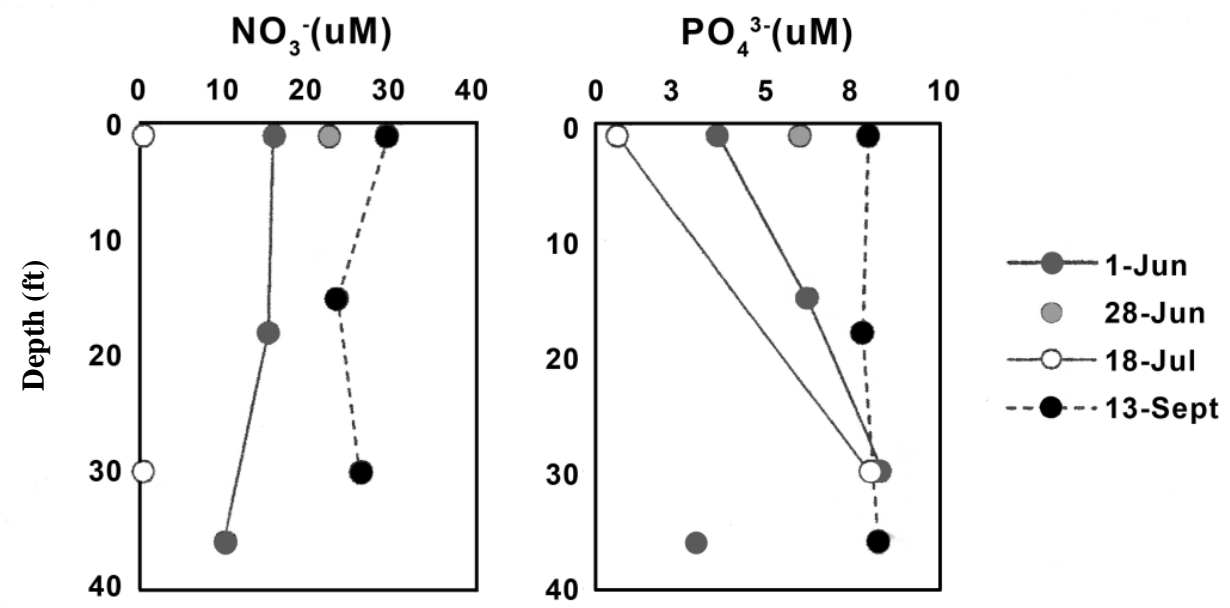

Fig. 2 Jamaica Bay dye inventory (estimated mass during mixing and dispersion) through time, measured during dye tracer experiments that included injections of fluorescein in June and September 2000, reproduced from original JABERRT Vol. I and Gordon et al. [13].

above this boundary. Scirpus and Typha seeds in the core were found in the lowermost section (at depths of $2.86 \mathrm{~m}$ and $2.76 \mathrm{~m}$, respectively). Charcoal occurred near $0.5 \mathrm{~m}$ depth. Wood appeared in two distinct sections of the core. The largest quantities were found in the deepest sample of $2.86 \mathrm{~m}$. Smaller amounts were found sporadically up the core until a depth of $2.35 \mathrm{~m}$. All fish scale artifacts were also found in the deepest meter. The bottom of the core was notable for dominance of Elphidium, a species of Foraminifera. A few Trochammina species and the only Rotamorphina species found in the core were present in this section $[5,13]$.

Results of dating the Jamaica Bay macrofossils revealed the base of the core to be $2,065 \pm 110 \mathrm{C}$ - 14 yr [13]. BP, with the date obtained from analyzing wood in sand, three major pollen zones were identified with preliminary counts of 100 pollen grains per sample. The earliest pollen zone $(190 \mathrm{~cm}$ to 115 $\mathrm{cm}$ ) was dominated by Quercus and Pinus.

Gramineae pollen was lowest in this zone. Ambrosia values were very low. The overlying zone $(110 \mathrm{~cm}$ to $40 \mathrm{~cm})$ showed increases in Ambrosia and decreases in Quercus and Pinus. The topmost zone $(30 \mathrm{~cm}$ to $0 \mathrm{~cm})$ showed declines in Ambrosia and increases in Gramineae [13].

\subsubsection{Temperature-Salinity Profiles}

Results by Gordon, A. L. et al. [13] depicted Jamaica Bay as a three-point mixing environment. For salinity less than $26.5 \mathrm{ppt}$ (mainly in eastern and northern Jamaica Bay), the temperature resided in the range of $23{ }^{\circ} \mathrm{C}$ to $24{ }^{\circ} \mathrm{C}\left(5^{\circ} \mathrm{C}\right.$ to $6^{\circ} \mathrm{C}$ warmer than the June condition). For salinity greater than $26.5 \mathrm{ppt}$ (western and southern Jamaica Bay), the temperature decreased with increasing salinity, with the most saline water of slightly higher than $30 \mathrm{ppt}$ at the Rockaway Inlet floor, representing the coastal water end-member. Below $5 \mathrm{~m}$ depth, salinity was $26.0 \mathrm{ppt}$ and Grassy Bay was filled with cooler water $\left(22-23{ }^{\circ} \mathrm{C}\right)$. This temperature was $5{ }^{\circ} \mathrm{C}$ above the June temperature at the bottom of Grassy Bay $\left(17.5^{\circ} \mathrm{C}\right)$, indicating that the period of stratification was less than three months [13].

The advection/diffusion model for Jamaica Bay was described by Gordon, A. L. et al. [13] and in the original JABERRT report [5]. In this system, cool, saline coastal water flows into Jamaica Bay via rockaway inlet and mixes with freshwater outflows via treated sewage. Grassy Bay in northeast Jamaica Bay is the area most isolated. Strong vertical mixing couples the inflow and outflow throughout Jamaica Bay. Below $5 \mathrm{~m}$, the water in Grassy Bay is relatively 
isolated from the more active adventive environment of the shallower layer of water. A simple salinity-mixing recipe assuming no net sea-air freshwater flux, suggests that the coastal end-member is about 4 times that of the fresh water flux. If the volume of Jamaica Bay greater than $5 \mathrm{~m}$ is $50 \times 10^{6}$ $\mathrm{m}^{3}$ and the fresh water flux is $50 \mathrm{~m}^{3} \cdot \mathrm{s}^{-1}$, then the bulk residence time of Jamaica Bay (not counting the portion of Grassy Bay below $5 \mathrm{~m}$ ) is 7 days. In addition, as identified by Gordon, A. L. et al. [13] and Tanacredi, J. T., and Schreibman, M. [5] from the "decay of dye inventories in Grassy Bay, e-folding (a metric of flushing rate) times of 2 days to 4 days were observed" (Fig. 2). It was estimated that Grassy Bay's bulk flushing time is approximately one week. This is a critical time period since regulatory agencies have utilized a 30-day to 35-day flushing rate for Jamaica Bay for 53 years. The 30 day flushing time was constantly used to justify a variety of environmental restoration projects from re-contouring the Jamaica Bay bottom to filling the subaqueous sand borrow pits with contaminated dredge materials [5].

Gordon, A. L. et al. [13] determined that, in general,
Jamaica Bay waters were enriched in phosphate (about $5 \mu \mathrm{m}$ ) relative to coastal waters but $\mathrm{N}\left(\mathrm{NO}_{2}+\mathrm{NO}_{3}\right)$ and $\mathrm{Si}$ concentrations $\left(\mathrm{N}\left(\mathrm{NO}_{2}+\mathrm{NO}_{3}\right), \mathrm{Si}\right.$ about $20 \mu \mathrm{m}$ ) did not appear to be anomalously high and all nutrient levels were higher in the northern regions of Jamaica Bay than in the well-mixed southern channel. In addition, nutrient profiles showed very little variability with depth, except in Grassy Bay, where circulation was restricted. In June and July, surface waters were depleted in $\mathrm{N}\left(\mathrm{NO}_{2}+\mathrm{NO}_{3}\right)$ and $\mathrm{PO}_{4}$, likely due to consumption by plankton. Bottom waters were depleted in $\mathrm{N}\left(\mathrm{NO}_{2}+\mathrm{NO}_{3}\right)$ but not $\mathrm{PO}_{4}$ (Fig. 3).

Oxygen bottle data revealed that surface waters of Jamaica Bay were generally well oxygenated throughout the year. The lowest oxygen concentration observed was $59 \%$ of saturation at the Fresh Creek station in September 2000 [13]. Gordon, A. L. [13] found thatnear bottom, oxygen saturation decreased during the summer as is expected due to the increase in summer water temperatures. The lowest oxygen concentration observed was $26 \mu \mathrm{m}$ at the deepest part of Grassy Bay in July. By September, the oxygen levels at this site had increased from $39 \mu \mathrm{m}$ to $105 \mu \mathrm{m}$. The

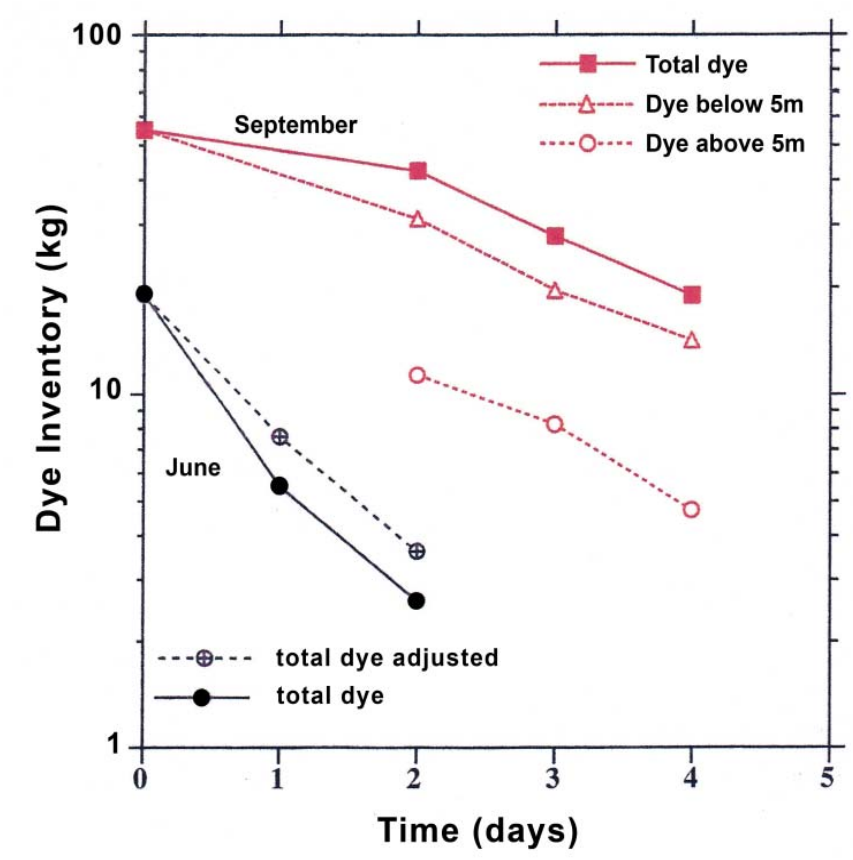

Fig. 3 Changes in water column concentrations of nitrate and phosphate throughout the summer in Grass Bay, Jamaica Bay, reproduced from original JABERRT Vol. I and Gordon et al. [13]. 
rest of the bay maintained bottom oxygen levels that would not be expected to cause stress to aquatic organisms. Top and bottom Dissolved Oxygen (DO) readings spanning some 24 years by NPS Division of Natural Resources at GNRA found similar results. DO levels at the surface and bottom regions have always been robust even during seasonal extreme variations of temperature [5].

Gordon, A. L. et al. [13] noted that there are two phytoplankton blooms in Jamaica Bay each year: a winter/spring bloom that can reach peak chlorophyll concentrations of $120 \mu \mathrm{g} \cdot \mathrm{L}^{-1}$ and a second weaker bloom during the summer.

The gradient in dissolved organic nitrogen compounds between Grassy Bay and the more rapidly flushed west channel station suggests that the organic constituents originate in the bay or its tributaries are flushed out through the mouth of the bay. Urban ecosystems such as Jamaica Bay have an inexhaustible nutrient supply (i.e. 320 million gallons of wastewater effluent into Jamaica Bay daily) [13]. Combined Sewer Overflows (CSO), atmospheric washing and storm water runoff all contribute to nitrogen in Jamaica Bay [27].

Based on the dye injection aspect of Gordon, A. L. et al., Tanacredi, J. T., and Schreibman, M. [5, 13], it was estimated that the residence of water shallower than $5 \mathrm{~m}$ in Grassy Bay is on the order of 7 days. This time is sufficient for biomass to increase to the highest level in the bay and for the Dissolved Inorganic Carbon (DIC) to decrease to the lowest level. It was suggested that the summer bloom collapsed due to the observed decline in concentration of $\mathrm{CO}_{2 \mathrm{aq}}$ during summer, which by mid-July reached a concentration of 2.4 $\mu \mathrm{mol} \cdot \mathrm{kg}^{-1}$ in the surface waters of Grassy Bay. Gordon, A. L. et al. [13] identified this concentration (less than $25 \%$ of the concentration available in normal seawater), while previous studies [28] have shown that such a decline would be strongly limiting to phytoplankton.

Patterns of nutrient depletion throughout the summer in Jamaica Bay suggest that surface concentrations of $\mathrm{N}\left(\mathrm{NO}_{2}+\mathrm{NO}_{3}\right), \mathrm{PO}_{4}$, and $\mathrm{Si}$ are regulated by biological productivity in the early to mid-summer [13]. Depletions of $\mathrm{Si}$ in late June suggest a diatom-dominated plankton assemblage. Gordon, A. L. et al. [13] identified the recovery of $\mathrm{N}$ and $\mathrm{Si}$ in September, which may suggest a shift to smaller algae that utilize a different nitrogen source. Depletions in bottom water $\mathrm{N}\left(\mathrm{NO}_{2}+\mathrm{NO}_{3}\right)$ in Grassy Bay relative to surface waters may have resulted from denitrification under low DO conditions. From early to late summer, there was an overall increase in $\mathrm{P}$ and decrease in $\mathrm{N}\left(\mathrm{NO}_{2}+\mathrm{NO}_{3}\right)$ throughout the water column of Jamaica Bay.

\subsection{Macrobentic Invertebrates}

Intertidal sand flats are ubiquitous and ecologically productive components of coastal ecosystems and are critical habitats for a number of estuarine fisheries in Jamaica Bay, including shrimp, blue crabs, hard shell clams and soft shell clam and horseshoe crabs [29-35]. Intertidal organisms have been shown to support higher trophic levels (e.g. blue crabs, juvenile flounders and many other fish species utilize intertidal sand flats for obtaining food and refuge during critical life history periods, as do migratory and resident shorebirds) [36-40].

Other than historical reports of Jamaica Bay fisheries, there is limited information about the species composition of Jamaica Bay invertebrates prior to 1972, when GNRA was established [8, 41]. Beginning in the early 1980 's, NPS sponsored several biotic surveys of Jamaica Bay [42]. Subtidal benthic communities were studied by Franz, D. R., and Harris, W. H. [25, 43]. Two studies of the effects of leachates from the north-shore landfills and the possible effects of hydrocarbon releases from JFK airport were inventoried for intertidal macroinvertebrate communities [15, 30, 37, 43-47]. A master's thesis by Choina, T. [48] also contains information on invertebrate communities within the Jamaica Bay Wildlife Refuge, with a particular focus on the effects 
of macroalgal (Ulva lactuca) blooms. Data in these last three unpublished studies form the basis of a detailed review on the factors affecting composition and diversity of intertidal sand flat communities in Jamaica Bay [49]. The JABERRT work is the first major documentation of salt marsh macrofauna and meiofauna in Jamaica Bay. A valuable series of papers on various aspects of the biology of Jamaica Bay amphipods have been published by Borowsky, B. et al. [45, 46, 50-58]. Likewise, there is a series of papers on salt marsh ribbed mussels (Geukensia demissa) from Jamaica Bay [15, 29, 30, 59, 60].

Considerable attention in estuarine environments is placed upon $\mathrm{CO}_{2}$ levels in benthic regions. The effect of prolonged hypoxia or anoxia on invertebrate resources has been previously documented, and possible invertebrate community shifts may be observed [2, 3]. However, the overall Jamaica Bay ecosystem benthic macro-invertebrate assemblages are robust and consistent based on JABERRT sample results from sites within the intertidal zone that were sampled based on their representation of the overall invertebrate community makeup for Jamaica Bay.
Invertebrate species dominance was measured as the sum of the percent of contributions of the two most abundant species in the combined replicates on any sampling date. A total of 41,159 macroinvertebrates, representing 105 taxa were identified from the 27 invertebrate sampling stations at 14 sites by Franz, D. R. [14]. Based on a cluster analysis of macroinvertebrates (Fig. 4), the salt marsh and epibenthic stations differed substantially in species composition and can be considered distinctly separate communities. However, the low intertidal and mud-flat community was closely linked to the sub-tidal association of species, and these two assemblages can be considered a single community, as suggested by Franz, D. R. et al. [49]. The significance of this result is that it differentiates marsh from intertidal/mud flat ecotypes and the invertebrate species that use these specific habitats. This type of clear delineation of habitat boundaries is needed to identify the scope and range of benthic community alteration and aid restoration efforts, particularly because different habitats and species require different restoration strategies.

\section{Unweighted Pair-Group Cluster Analysis of Jamaica Bay Macroinvertebrate by Site}

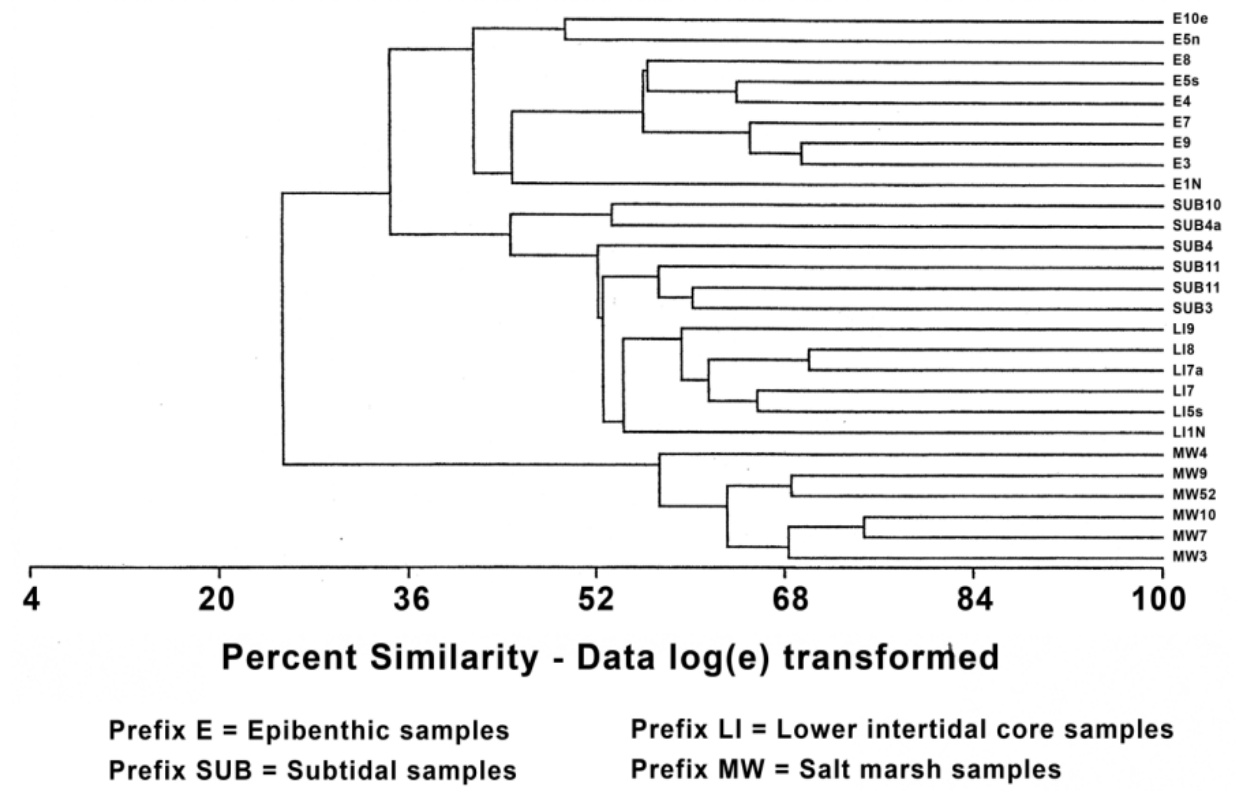

Fig. 4 A cluster analysis of macroinvertebrates from four sample types taken at all sites in Jamaica Bay [15]. 


\subsection{Fisheries Inventory}

\subsubsection{Abundance}

Jamaica Bay is a significant nursery ground for commercially and recreationally important finfish such as the winter flounder and striped bass [61-63]. The majority of finfish species caught in the bay during the study period were juveniles. In this study, the Atlantic silverside (Menidia menidia) was the most frequently captured finfish by seining, comprising $61 \%$ of all species caught (Fig. 5, left) [5]. The silverside continues to be one of the most abundant juvenile fish in Jamaica Bay, as well as throughout the Middle Atlantic Bight (Fig. 5, right) [64].

The second most frequent group of finfish captured by seining were Fundulus species, including the striped killifish and marsh killifish, comprising 25\% of species captured. The third most prevalent species caught by seining was the Atlantic menhaden at $4 \%$, followed in fourth place by the striped mullet and the winter flounder, both at $1 \%$.

The most abundant species captured by trawling was the winter flounder, Pleuronectes americanus (Fig. 6) at nearly one third or $31 \%$ of all fish trawled. The second most abundant species captured by trawling was the summer flounder (Paralichtyes

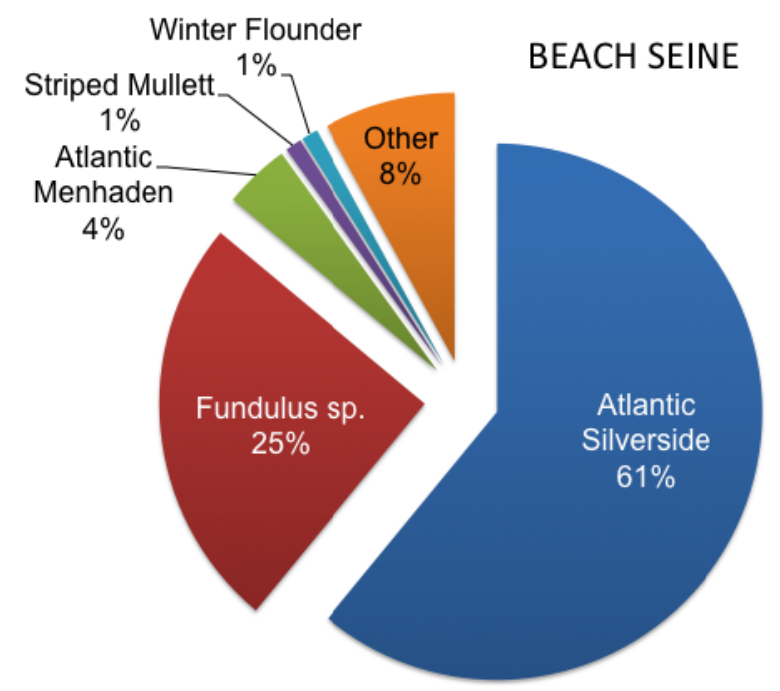

dentata) at $10 \%$, followed by the window pane flounder (Scopthalmus aquosus) at $6 \%$, and the spotted hake (Urophycis regia) at 5\%. All these are commercially and recreationally important fish, and size limits on the catch have been imposed on all species except the hake. The range of trawl site depth was 21.5-35 ft. (Fig. 1, fisheries trawl sites).

\subsubsection{Comparison to Other Fisheries Studies}

During the 13 months of this portion of the JABERRT study, a total of 49 fish species were caught. In previous NYSDEC Jamaica Bay fisheries studies, the numbers of finfish species caught ranged from 27 to 38 for six months from May through October 1984 to the present. From April to October 1999, the NYSDEC ran an inventory study in Jamaica Bay that identified 37 finfish species during six months [16].

This study compared the community structure of Jamaica Bay with the results of a NYSDEC study that began in 1986 and the NPS Jamaica Fisheries Survey conducted during 1985 to 1986 and 1988 to 1989 . The results of the two studies were similar. For example, the most abundant finfish caught in the JABERRT study was the Atlantic silverside. These data were consistent with seining done in the waters of western

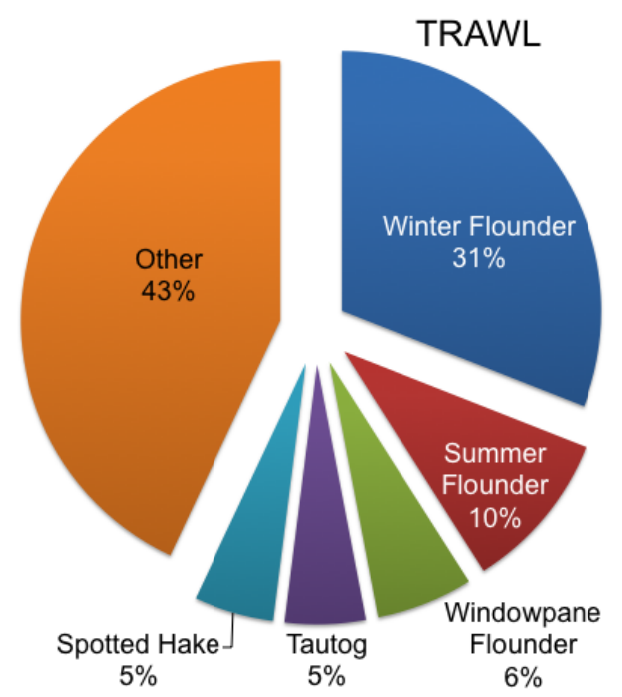

Fig. 5 Percent of fish species captured by beach seine (left) or trawl (right) during May 2000-May 2001(modified) [5]. 


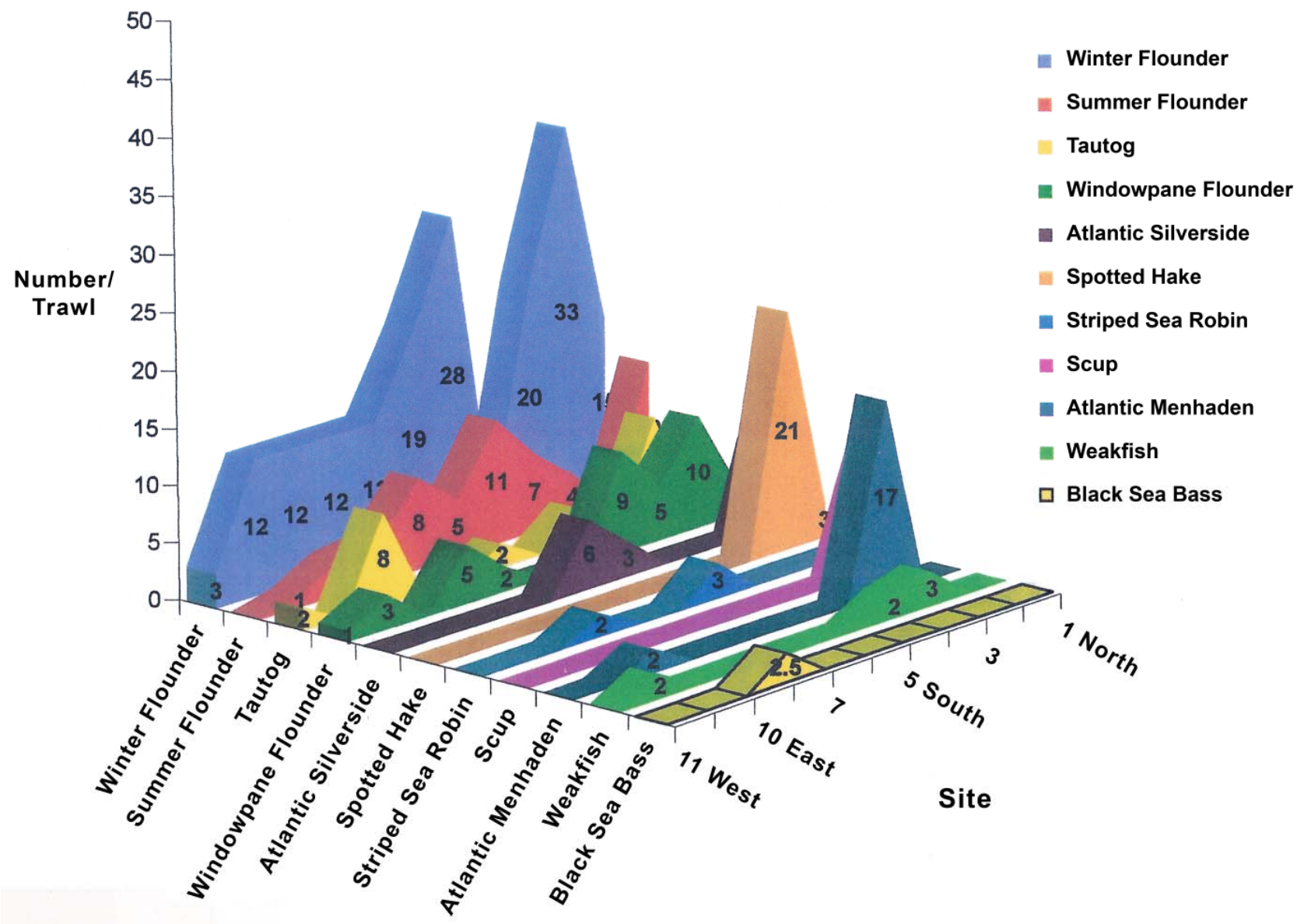

Fig. 6 The number of finfish captured per trawl event at each sitefrom May 2000-May 2001 [5].

Long Island by the NYSDEC from 1986 to 2000, which found that the Atlantic silverside was the dominant species caught ( $41 \%$ to $86 \%$ of the catch) per year [16]. Similarly, in both NPS studies, the Atlantic silverside was the most abundant fish caught by seining. Fundulus species (including striped, spot fin and marsh killifish) comprised $25 \%$ of species caught in the JABERRT study, the second most prevalent species. NYSDEC again showed Fundulus species to be the second most predominant species from 1986 to the present, with different species (the Atlantic herring) in second place only in 1996. This finding was corroborated in the NPS studies.

The third most prevalent species caught by seining in the JABERRT study was the Atlantic menhaden. NYSDEC data show the bay anchovy as third in 1986, 1988-1991, and 1998. The winter flounder occupied the third position from 1992 to 1995. In 1996, third place was held by the striped bass. In the NPS study, from 1985 to 1986, the mummichog (Fundulus heteroclitus) was third, while in 1988 and 1989, bluefish (Pomatomus) took that spot. Striped mullet $(1 \%)$ and winter flounder (1\%) were fourth and fifth in the JABERRT study. In NYSDEC studies [16], these places were filled by many different species, including bluefish, winter flounder, Atlantic herring, striped bass, bay anchovy, sandlance (Ammodytidae), northern pipefish (Syngnathus fuscus) and Fundulus. The shift from pelagic species to benthic species habitat provides an indication of the importance of bottom-lands in species selection. This aspect of JABERRT requires further study.

The largest population of winter flounder was found in May 2000, with the highest number of Young-of-the-Year (YOY) flounder in June 2000. Conversely, May 2001 had one of the lowest counts of 
adult winter flounder with the highest population count in March. The highest YOY counts were observed in March and April 2001. These findings are consistent with temperature-dependent known life history patterns [65]. In the Great Bay area in New York, annual variation in abundance of Atlantic silversides is also comparable to YOY in Little Sheepshead Creek and Jamaica Bay.

When JABERRT data on the composition and number of species are compared to NPS trawling data, they show a decrease in the number of winter flounder caught in the bay since 1989. In 1985, winter flounder accounted for more than $44 \%$ of the catch in trawls, and in 1989, the figure was more than $47 \%$. JABERRT data show a drop to $31 \%$ in 2001 . The JABERRT comparison also shows that the percentage of the other "top five" fish caught in the bay (summer flounder, windowpane flounder, etc.) decreased from both the 1985 and 1989 figures, except in the case of spottedhake in 1989 [38]. Variation in the numbers and percentages of other fish in the bay have been reported (e.g. a drop in Atlantic cod, bay anchovy, weakfish, scup, Black Sea bass and an increase in adult fish considered baitfish such as Atlantic menhaden) [66]. Similar results were found during seining of juveniles by NYSDEC from 1984 to 1998 in western Long Island. Potential declines of finfish at different stages of development in Jamaica Bay merits further investigation.

\subsection{Avifauna Inventory}

Veit, R. R. et al. $[17,67,68]$ ranked sample sites by overall history of species abundance. Many migratory shorebirds feed and roost at Jamaica Bay Wildlife Refuge and in the salt marshes of Jamaica Bay [68]. A substantial number of these birds spend the entire winter in Jamaica Bay, provided the bay doesn't freeze over, though counts from the sites censured do not reflect their abundance in Jamaica Bay as a whole.

The Jamaica Bay Wildlife Refuge provided more than 50 years of bird observation data to aid in developing monitoring sites for specific avifauna varieties collected at harrier banding stations, Neotropical nesting sites (mist-net data), colonial waterbird colonies and other locations (Fig. 1). A total of 22 species of shorebirds were recorded during the year of the JABERRT study. While the numbers of birds reported at each site were modest, nevertheless, survey of the JABERRT sites [17] indicated that the sites represent substantial habitat for migrating shorebirds.

\subsubsection{Abundance}

Veit, R. R. et al. [17] reported that the greatest abundance of all birds occurred on Sites 5S, 7 and 1 . The numerically dominant species was, by a wide margin, American brant (Branta bernicla), an important consumer of eelgrass, Ulva spp. and also grass on the lawns of parks and golf courses. Brant are principally migrants through Jamaica Bay with peak abundance in May and October-November (Fig. 7). As reported by Veit, R. R. et al. [17], maximum counts included 1,000 at Site 5S (1 November 2001) and 750 at Site 7 (20 October 2001). Counts of 10,000 or more have been made at Jamaica Bay in recent years [69-71].

Veit, R. R. et al. [17] identified a substantial number of waterfowl species that ordinarily breed to the north of the New York city area were found summering along the perimeter of the bay, especially in Site 1. As many as six red-breasted mergansers (Mergus serrator) were found there. This species has bred on Long Island previously, as recently as 1953 at Jones Beach [69], suggesting that Dead Horse Bay represents a potential future nesting site. Other summering waterfowl recorded at Site 1 included greater scaup (Aythyamarila) and surf scoter (Melanitta perspicillata) [17].

Five and nine species of herons were seen on each site. The largest number of these species were seen on sites $5 \mathrm{~N}$ (9 spp), Site 2 (8 spp) and Site 5S (7 spp). Considering the numbers of herons breeding in Jamaica Bay (e.g. hundreds of pairs of black-crowned 

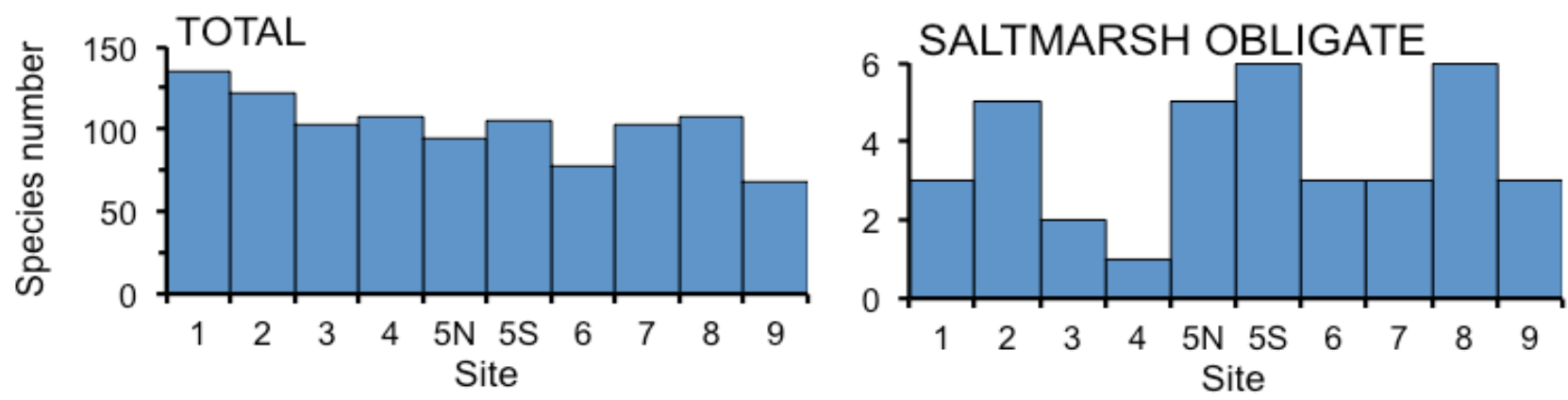

Fig. 7 Numbers of total (left) and saltmarsh obligate (right) shorebirdspecies per site at 10 sites in Jamaica Bay, as redrawn from Viet, R. R. [17].

night-herons (Nycticorax), snowy (Egrettathula) and great (Ardeaalba) egrets and glossy ibises (Plegadis) during the 1990s at Carnarsie Pol and other Jamaica Bay colonies)), relatively small numbers of herons were seen at the study sites. The main exception to this pattern was the yellow-crowned night heron (Nyctanassan violacea), which, unlike the other species of herons, is a solitary nester and feeder.

Yellow-crowned night herons were common at sites along the north shore of Jamaica Bay, suggesting these sites represent important foraging habitat for this species. As many as eight yellow-crowned night-herons at a time were seen on Site 4 . This is a substantial proportion of the New York State population (averaged 22 nesting pairs between 1985 and 1995). Although outside of the sampling period, three pairs of breeding yellow-crowned night-herons were located at the northern tip of Canarsie Pol in June 2001. A second exception to the pattern of low abundance of herons on the survey sites were counts of 180 glossy ibises at Site 5S (23 April 2001) and 40 at the same location (14 May 2000) [17].

While total numbers were modest, the numbers of some individual species at JABERRT sites during some periods were high. For example, 53 lesser yellowlegs (Tringa flavipes) at Site 4 (5 August 2000) was a large number for this bird, a habitat specialist, and likely signifies the presence of either high quality foraging grounds, safe roosting sites or both [72]. Other shorebirds for which high counts were obtained included: (a) laughing gulls from the large breeding colony on the salt marshes near JFK airport, which were numerous from April to early November [73] and (b) Neotropical migrant land birds at Sites 1 (28 species), 7 (22 species), 2 and 4 (20 species each). Scrublands and thickets characterized each site. The most numerous Neotropical migrant was the barn swallow (Hirundorustica), which made up close to $50 \%$ of all birds in this group at some sites. The next most numerous species were the willow flycatcher (Empidonax traillii) and the yellow warbler (Dendroica petechial); both are common breeders in the Jamaica Bay area $[17,74]$.

\subsubsection{Diversity}

According to Veit, R. R. et al. [17], there was no dependence of species number on the areas encompassed by the sample site $(r s=0.01, p=0.49$ and $n=10$ ) even though Site 1 was the largest area with the largest species total. The best sites in terms of species diversity were Site 1 (17 species), Site 8 (16 species), Site 5S (14 species) and Site 5N (13 species) [74-76]. Site 1 likely hosted the most diverse array of species by virtue of the diversity of both the estuarine and terrestrial habitats that it encompasses. Six species of birds that depend on salt marsh habitats for their entire breeding season were identified: clapper rail (Rallus longirostris), willet (Cataptrophorus semipalmatus), forster's tern (Sterns forsteri), salt marsh sharp-tailed sparrow (Ammodramus caudacutus), seaside sparrow (Ammodramus maritimus) and boat-tailed grackle (Quiscalus major).

The objective for JABERRT was to use the 
presence of these species as a clue to the quality of the salt marshes on each of the sampling sites. Two of the sites were surveyed, Site $5 \mathrm{~S}$ and Site 8 , which had all six species. Two others, Site $5 \mathrm{~N}$ and Site 2 had five of the species. None of the other sites had more than three species. Using the presence of breeding salt marsh-obligate birds as criterion, Site $5 \mathrm{~S}$ and Site 8 seemed to have the highest quality salt marsh habitats.

Site $5 \mathrm{~S}$ and Site $5 \mathrm{~N}$, near the Pennsylvania and Fountain Avenue landfills, prior to the creation of the landfills, were exceptional localities for shorebirds, especially curlew sandpipers (Calidris ferruginea) [69]. It is noteworthy that these flats still seem to attract migratory shorebirds, likely due to the availability of horseshoe crab eggs in June/July and despite habitat degradation due to waste disposal and landfill leachate $[4,40,76]$.

\subsection{Environmental Contaminants}

Quinn, J. URI-GSO collected all surface soils and subaqueous sediment samples (Fig. 1) which were analyzed for a variety of metal and organic contaminants (Table 3, Fig. 8) [5]. The contaminants selected for analysis were based on recommendations made by the NOAA Status and Trends Program for Estuarine and Coastal Monitoring. Great variation in the concentrations of organic contaminants and trace metals were found among the samples (Figs. 8 and 9). These results were compared with "effects-based guidelines" that help to identify where the potential for biological impact was greatest. The two guideline values were Effects Range Low (ERL) and Effects Range Median (ERM), which defined concentration ranges that were either rarely $(<\mathrm{ERL})$, occasionally $(>$ ERL but $<$ ERM) or frequently ( $>$ ERM) associated with adverse biological effects [77]. The contaminant states of sample sites are noted for each restoration site (Table 2).

Samples of submerged sediments $(0 \mathrm{~cm}$ to $20 \mathrm{~cm}$ depth, Table 3) were also collected along two transects from the landfills to the center of Jamaica Bay (Fig. 1). The transect from Pennsylvania Avenue

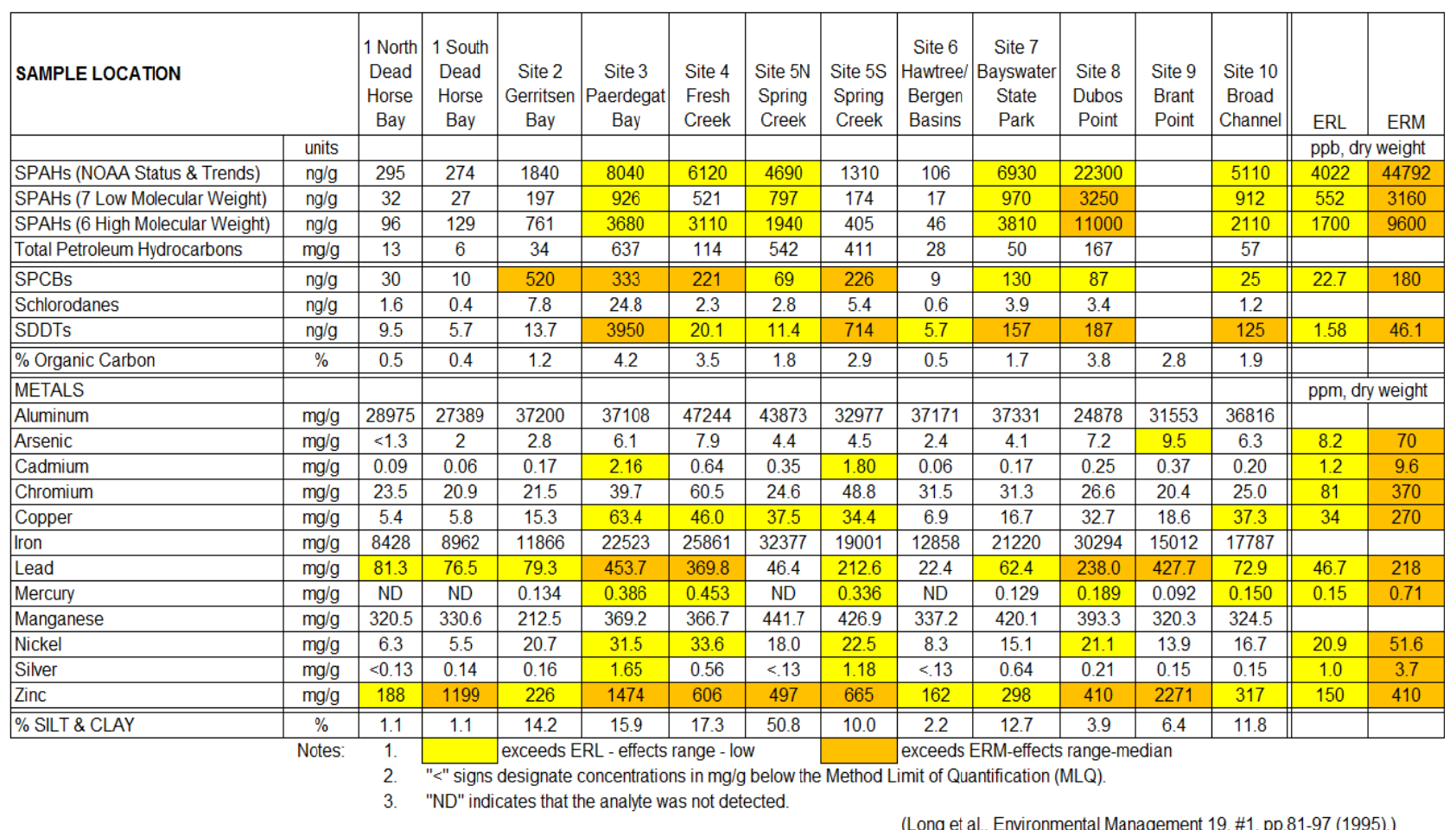

Fig. 8 Surface sediment contaminants, including Polycyclic Aromatic Hydrocarbons (PAHs), Polychlorinated Biphenyls (PCBs), organochloride (chlordane), Dichloro Diphenyl Trichloroethane (DDT), metals and organic and texture composition at JABERRT sites [5]. 
Table 2 Results of contaminant analyses on upland surface soils (0-20 cm depth) at the JABERRT sites (cf sites in Fig. 1) [5].

\begin{tabular}{|l|l|}
\hline Site 1: $\quad$ Dead Horse Bay exceeded ERL with PCBs, DDTs, lead, zinc and exceeded ERM with zinc. \\
\hline Site 2: $\quad$ Gerritsen Creek exceeded ERL with DDTs, lead, zinc and exceeded ERM with PCBs. \\
\hline $\begin{array}{l}\text { Site 3: } \quad \text { Paerdegat Basin exceeded ERL with PAHs, 7-low-molecular-weight PAHs, 6-high-molecular-weight PAHs, cadmium, } \\
\text { copper, mercury, nickel, silver and exceeded ERM with PCBs, DDTs, lead and zinc. }\end{array}$ \\
\hline $\begin{array}{l}\text { Site 4: } \quad \text { Fresh Creek exceeded ERL with PAHs, 6-high-molecular-weight PAHs, DDTs, copper, mercury, nickel and exceeded } \\
\text { ERM with PCBs, lead and zinc. }\end{array}$ \\
\hline $\begin{array}{l}\text { Site 5: } \quad \text { Spring Creek exceeded ERL with PAHs, 7-low-molecular-weight PAHs, 6-high-molrcular-weight PAHs, cadmium, } \\
\text { copper, lead, mercury, nickel, silver and exceeded ERM with PCBs, DDTs and zinc. }\end{array}$ \\
\hline $\begin{array}{l}\text { Site 7: } \quad \text { Bayswater State Park/Noroton Basin exceeded ERL with PAHs, 7-low-molecular-weigh PAHs, 6-high-molecular-weight } \\
\text { PAHs, PCBs, lead, zinc and exceeded ERM with DDTs. }\end{array}$ \\
\hline $\begin{array}{l}\text { Site 8: } \quad \text { Dubos Point exceeded ERL with PAHs, PCBs, mercury, nickel, and exceeded ERM with 7-low-molecular-weight PAHs, } \\
\text { 6-high-molecular-weight PAHs, DDTs, lead and zinc. }\end{array}$ \\
\hline Site 9: $\quad$ Brant Point exceeded ERL with arsenic and exceeded ERM with lead and zinc. \\
\hline
\end{tabular}

Table 3 Results of contaminant analyses on submerged sediments (0 to $20 \mathrm{~cm}$ depth) collected along shorelines, on mudflats and sandbars, and in the navigation channels at JABERRT sites [5].

\begin{tabular}{|c|c|}
\hline Site 1: & ead Horse Bay at the shoreline exceeded ERL with DDTs, lead, but did not exceed ERM. \\
\hline Site 2: & Creek at the shoreline exceeded ERL with silver, but did not exceed ERM. \\
\hline $\begin{array}{l}\text { Site 3: } \\
\text { ERM w }\end{array}$ & $\begin{array}{l}\text { rdegat Basin below 3m water depth exceeded ERL with DDTs, arsenic, lead, mercury, nickel, silver and exceeded } \\
\text { Bs. }\end{array}$ \\
\hline $\begin{array}{l}\text { ite 5: } \\
\text {-high-1 } \\
\text { nercury }\end{array}$ & $\begin{array}{l}\text { oring Creek shoreline, mudflat, and below } 3 \mathrm{~m} \text { water depth exceeded ERL with PAHs, 7-low-molecular-weig } \\
\text { ular-weight PAHs, arsenic, cadmium, chromium, copper, nickel, zinc, and exceeded ERM with PCBs, DI } \\
\text { silver. }\end{array}$ \\
\hline Site 6: & Hawtree/Bergen Basins at the shoreline exceeded ERL with DDTs, but did not exceed ERM. \\
\hline Site 7: & Bayswater State Park. Norton Basin at the peat shoreline exceeded ERL with DDTs, arsenic, but \\
\hline Site 8: & Dubos Point at the shoreline exceeded ERL with PCBs, DDTs, lead, but did not exceed ERM. \\
\hline $\begin{array}{l}\text { Site } 9 \\
\text { PAHs }\end{array}$ & $\begin{array}{l}\text { rant Point at the peat shoreline and below } 3 \mathrm{~m} \text { water depth did not exceed ERL with PAHs, 7-low-molecular-weig } \\
\text {-molecular-weight PAHs, DDTs, arsenic, copper, lead, mercury, nickel, silver and exceeded ERM with PCBs. }\end{array}$ \\
\hline ite 1 & $\begin{array}{l}\text { fffle Bar below } 3 \mathrm{~m} \text { water depth exceeded ERL with PCBs, DDTs, arsenic, copper, lead, mercury, nickel, sil } \\
\text { M. }\end{array}$ \\
\hline
\end{tabular}

landfill to Yellow Bar Hassock included shoreline with and without peat, mudflats and sediment below $3 \mathrm{~m}$ water depth. ERL was exceeded with PAHs, 7-low-molecular-weight PAHs, 6-high-molecular-weight PAHs, PCBs, DDTs, arsenic, copper, lead, nickel and silver, and ERM was exceeded with mercury. The transect from the Fountain Avenue Landfill to Elders Point Marsh included shoreline without peat, mudflats and sandbar, and below $3 \mathrm{~m}$ water depth, ERL was not exceeded. Concentrations of metals and organics were highly variable $[78,79]$.

\subsection{Vegetation Results}

The vascular flora of the 12 JABERRT sites are summarized by site in Table 4 (Fig. 1) [80]. Upland terrestrial plant communities were predominantly non-native species at all sites [5].

\subsection{Water Quality Results}

Jamaica Bay has endured decades of environmental impacts [2, 3, 81-85]. Urban ecosystems experience the influences of varied assaults on natural resources generally from large human populations. In 1969 in response to a proposal to expand an airport runway into what is now the Jamaica Bay Wildlife Refuge and significant urban natural area, the NAS conducted a total ecosystem inventory and pre-NEPA-era environmental impact assessment [86]. A proposed 
Table 4 Total vegetation types found at 12 JABERRT sites, site numbers correspond to sites indicated in Fig. 1.

\begin{tabular}{|c|c|c|c|}
\hline Site & Total vascular plant species/dicots/monocots & Non-native (\%) & Rare plants \\
\hline 1. Dead Horse Bay & 153/21/31 (1 Fern) & $51.5 \%$ & Cuscuta/pentagona \\
\hline 2. Gerritsen Creek & $136 / 112 / 24$ & $52.9 \%$ & Cyperus/schweinitzii \\
\hline 3. Paerdegat Basin & $116 / 97 / 19$ & $51.7 \%$ & Aster tenuifolius \\
\hline 4. Fresh Creek & $162 / 131 / 30(1$ Fern $)$ & $54.3 \%$ & Aster subulatus \\
\hline 5. Spring Creek & $\begin{array}{l}\text { 143/119/23(1 Pinophya) } \\
\text { Pinusthunbergii }\end{array}$ & $58 \%$ & Trades/cantiaohiensus \\
\hline 6. Hawtree/Bergen Basin & $\begin{array}{l}\text { 170/138/31 (1 Pinophya) } \\
\text { Juniperus virginiana }\end{array}$ & $50 \%$ & Cuscuta/pentagona \\
\hline 7. Bayswater & 185/152/33 (1 Pinophya $)$ & $48.1 \%$ & Aster/tenuifolius \\
\hline 8. Dubos Point & 71/47/22 (1 Pine) & $45 \%$ & ---- \\
\hline 9. Brant Point & $50 / 38 / 12$ & $42 \%$ & ---- \\
\hline 10. Broad Channel & $68 / 58 / 10$ & $54.4 \%$ & $\begin{array}{l}\text { Solidago/semperivirens } \\
\text { Var. mexicana }\end{array}$ \\
\hline 11. JFK & $25 / 7 / 8$ & $44 \%$ & ---- \\
\hline 12. Ruffle Bar & 106/88/16 (1 Fern) & $42.4 \%$ & ---- \\
\hline
\end{tabular}

additional runway at JFK Airport was never built, but the comprehensive environmental assessment provided a snap shot of the Jamaica Bay ecosystem that would not be repeated at the same investigative level until 1999-2000 with the JABERRT project.

With the creation of the Nation's first urban National Park Unit GNRA in 1972, this NAS initial ecosystem study became the seminal baseline statement of ecosystem health for Jamaica Bay's subsequent protection. Even under the management of the National Park Service, a considerable number of competing interests (including U.S. Army Corps of Engineers repeated attempts to dispose of contaminated dredged spoil into Grassy Bay) continued wastewater discharge and CSO contributions of environmental contaminants [87-90]. Continuous attempts at airport runway extension, active and aggressive bird population control by the Port Authority of NY/NJ, sanitary landfill closures and leachate control, actively threaten this urban park recreational facility [90]. Development of commercial and residential housing property at the federal, state and local levels of government continuously threaten to shift the emphasis of the Jamaica Bay Refuge in GNRA, from "protect and preserve [...] the wildlife therein $[\ldots]$ for future generations in perpetuity," to urban infrastructure, an example of a significant paradigm shift $[4,80]$. For more than 40 years, the many competing uses of Jamaica Bay appear to have perpetuated the myths of degradation and poor ecological health that have been used, in turn, to influence management and justify ongoing urbanization and expansive infrastructure.

Closure of three sanitary landfills (Pennsylvania Avenue, Fountain Avenue and Edgmere Landfill) in 1985 helped reduce leachate pollutant impacts. Yet the pressures of urbanization continue to mount. For example, 320 million gallons per day of treated wastewater discharges, CSO discharges, atmospheric washings in conjunction with disposal proposals to use subaqueous borrow pits in Jamaica Bay for contaminated dredged material disposal. Coastal energy development using open spaces of the park as energy corridors for oil and natural gas, transportation upgrades and a major commercial development, the Vandalia Dunes mega-mall, which ultimately caused the loss of over 20,000 trees and 3 acres of Spartinaalfern flora marsh, the water quality of the Jamaica Bay ecosystem was increasingly impacted. Administratively, Jamaica Bay could only be designated a "degraded ecosystem" by federal and state agencies. It was JABERRT's investigation that would prompt a re-evaluation of the water quality condition, thus the ecological functioning of Jamaica 
Bay, to protect it into the future. It was the corroborative designation by administrative agencies and groups that Jamaica Bay's degraded water quality status allowed for the developmental scenarios to be considered in spite of its significant need for conservation.

Water quality annually monitored for 24 years in Jamaica Bay by the NPS, along with bathing beach water quality monitored by NYCDEP seasonally in summer, revealed rich oxygen concentrations for "fishing standards support" and for "contact recreational beaches: for bacterial concentrations". All JABERRT and NPS water quality data were incorporated in the US EPA STORET data system. Review of these data found that $<0.01 \%$ of some 24 years of data ( 2 days) had DO concentration below 1.0 $\mathrm{mg} \cdot \mathrm{L}^{-1}$. During only $0.07 \%$ of the time (6 days), bathing beaches were closed for contact recreational use, and all of these events occurred during the summer of a single year (1988).

\section{Discussion}

After analysis and evaluation of earlier assessment reports that focused essentially on transportation issues (expanding the JFK airport) and the possible impacts on Jamaica Bay, these results reveal a number of apparent inconsistencies and glaringly unsupported statements. Unfortunately, these data have led to questionable practices that have governed management plans for this NY estuary. JABERRT presents these bias data used for major developments in Jamaica Bay that have been perpetuated as the "myths".

\subsection{Effects of Saltmarsh Habitat Loss and Instability}

The JABERRT investigation was the only study that focused specifically on epibenthic macroinvertebrates associated with Spartina alterniflora and sediments in a low marsh setting. With a few exceptions, species richness and diversity at low, intertidal and sub-tidal sites generally were similar to results from previous studies in Jamaica
Bay and other estuarine sites [91-94]. This study revealed surprisingly large numbers of species and individuals occupying the sediment surface above MLW and on the salt marsh surface, even at stations that may be considered "unstable" and/or "degraded" by regulatory agencies. JABERRT also demonstrated that the diversity and density of the marsh community varied independently of stations at the same site but lower in the intertidal zone. This intertidal richness was constantly ignored in regard to proposals for development that would eliminate this habitat type [43]. JABERRT revealed that this ecotype was significant ecologically and warranted continued and added protection. The authors attempted to create an LTER under the National Science Foundation, but were not successful. It may be time, post Superstorm Sandy to reconsider this effort.

\subsection{Hydrodynamics and Water Quality Degradation}

Data derived from the 1969 NAS study indicated that Jamaica Bay required 30 days or more to flush tidal waters from peripheral inlets, which was determined to be the major causative factor for perceived degraded conditions in the Jamaica Bay system. Distribution of water properties defines the integrated effects of tidal and non-tidal circulation and mixing processes [5, 13]. The JABERRT studies dispelled the myth of prolonged retention time in dramatic fashion when it was determined that the flushing rate of Jamaica Bay is closer to 7 days rather than the 30 days perpetuated [13]. This fact greatly impacts how scientists examine ecological issues and concerns for the bay, especially related to salt marsh loss and water quality

In recent years, there have been major projects to restore receding salt marsh islands (Big Egg 2003, Elders East 2006, Elders West 2010, Yellow Bar and Black Wall 2014) in Jamaica Bay by adding dredged material coupled with Spartina plantings. It will be interesting and important to observe the fate of these efforts in coming years through continuous 
monitoring in the context of JABERRT findings on hydrodynamics and sediment budgets.

NPS monitoring of Jamaica Bay water quality from the late 1970s through the mid-1990s documented that periodic DO depletion or hypoxic events (i.e. DO below $3 \mathrm{mg} \cdot \mathrm{L}^{-1}$ ) occurred with increasing seasonal summer surface water temperatures [3-4, 6, 95]. Routinely, New York City discharges 360 million gallons of treated wastewater daily into Jamaica Bay. This effluent contributed to N-rich discharges that spurred episodic "cultural eutrophication" blooms, resulting in periodic fish kills and, in the deepened portions of the inner bay, depressed DO values in bottom waters.

In the entire USEPA Storet retrieval and storage data system, which included all NPS Jamaica Bay water quality data since 1978, only three incidents occurred where DO concentrations were less than 1.0 $\mathrm{mg} \cdot \mathrm{L}^{-1}$, and not a single event exceeded one-day duration. Water quality in Jamaica Bay has exhibited dramatic improvements during the last 43-year period since the creation of the National Park Unit, G-NRA in 1972. Although still a concern, New York City wastewater treatment improvements have significantly contributed to reducing Nenrichment. In spite of the typical estuarine hydrodynamics of Jamaica Bay, which exhibit temperature stratification events during peak summer periods, no recorded continuous anoxia has ever been observed during the 27 years of monitoring by NPS, NYCDEP, USEPA and several consulting firms.

The myth of chronic anoxia and habitat loss due to poor water quality seems to be propagated largely due to ongoing citation of old data collected during periods of time when conditions were severe. For example, annual reports by NYCDEP [96] stating that Jamaica Bay is a "stressed and a degraded estuary requiring restoration or mitigation" were based on DO concentrations measured during summer periods when air temperatures were higher than usual in New York city (between 1985 and 1993) and concurrent with
N-rich treated sewage discharges into Jamaica Bay.

Overall, Jamaica Bay is a dynamic system in which water quality, hydrodynamics and sediment composition are continuously changing, due in part to the strong tidal movements that occur each day. To fully evaluate water quality, therefore, 24 hour monitoring would be needed throughout the Bay.

\subsection{Salt Marsh Loss}

Similarly, NYSDEC identified loss of Spartina marshes in portions of Jamaica Bay's interior as "sloughing off" and "eroding" due to anthropogenic factors such as boat wakes, landfill leachates (known to have received more than 30 million gallons of waste crankcase oil discharged during 25 years of operation by the NYC Department of Sanitation), fuel discharges from JFK Airport, dredging activities in the rockaway inlet entrance and possible sea level rise [97]. Any of these issues may have made a measureable contribution to marsh loss. It was only after JABERRT hydrodynamics and hydraulics investigations of tidal flows through the rockaway inlet, that naturally occurring hydrodynamic processes were determined to be the major cause of fine sediment removal from the Jamaica Bay interior, preventing natural marsh re-establishment and re-vegetation. The extremely rapid hydraulic draw on each tidal cycle through the rockaway inlet (Fig. 1) removes the fine sediment and organic suspended particulates that would constitute the main materials to maintain natural marsh growth and natural restoration processes for water quality [98].

This natural hydrologic process was found to further influence bloom conditions [13]. The $\delta^{13} \mathrm{C}$ composition of local particulate organic matter was significantly positively correlated to the concentration of Particulate Organic Carbon (POC) in Jamaica Bay. The interdependence of natural hydrodynamic processes, water quality and habitat stability in Jamaica Bay requires further investigation and consistent periodic monitoring. 


\subsection{Subaqueous Borrow Pits Filled in Restore Bay Flushing}

Efforts to restore bay flushing were almost always based on inadequate or erroneous information, such as the movement to "fill in" sub-aqueous borrow pits, previously sand mining sites in the head of the bay (Grassy Bay) and adjacent to where dredged fill was deposited to create JFK Airport. Agencies that promoted filling in the subaqueous borrow pits, generally employed vague terms (e.g. "revitalization", "corrective action", etc.) that were never rigorously defined. In addition, they promoted filling based on their specific agency mandates, which were not necessarily compatible with the conservation of Jamaica Bay. Many of these proposals were prevented only due to Jamaica Bay's status as a National Wildlife Refuge under the National Park Service and efforts of $\mathrm{NGO} /$ public oversight citizen groups (e.g. Jamaica Bay Eco. Watchers, Jamaica Bay Guardian/American Littoral Society, NYC Audubon, Sierra Club and NRDC).

Agencies with "conservation" as primary mandates, promoted "restoration" based on erroneous and mostly computer modeled and limited scientific data. The agency that most aggressively pursued plans for filling in the borrow pits in Jamaica Bay was the USACE, which suggested filling the pits with "clean fill" or "contaminated fill with a clean sand cover". The NYCDEP also suggested filling the pits to "re-contour the bay bottom", on the assumption that doing so would "promote faster and beneficial drainage of the bay during each tidal cycle". The NYSDEC, which previously designated Jamaica Bay a "critical environmental area", suggested filling the pits to restore what was presumed to be a "degraded portion of Jamaica Bay" or as a compromise, filling the pits to accommodate "low grade but not contaminated dredged material disposal". The NY/NJ HEP-Habitat Restoration Committee under the USEPA's National Estuary Program proposed filling the pits to promote "increased flushing of the bay since the Bay's 30 day tidal flushing cycle (inaccurate since the 1969 NAS study incorrectly identified this time frame), which was presumed to permit low quality water to linger in the bay, thus encouraging hypoxia". Today, some 15 years after the JABERRT report was completed and provided to these agencies, many still cling to "policies" for restoration that are counter to the rigorous scientific data indicating such efforts are unnecessary $[5,99]$.

\subsection{Landfill Contaminants and Sediments}

In 1985, the Pennsylvania/Fountain Avenue Landfills (PAL/FAL) were closed to receiving solid waste. The NPS prepared a Natural Resources Damages Claim (NRDC) in response to the damages incurred by 30 million gallons (estimated) waste oil leachate to Jamaica Bay from these landfills [100]. Even though this NRDC claim was never initiated, a panoply of government agencies and private citizen "conservation" groups plugged away at trying to get "restoration practices formulated for Jamaica Bay" despite the limited amount of research data upon which to base management policy [101-103]. In 1999, a Blue Ribbon Panel (chaired by the first author of this manuscript) was assembled to explore the causative factors of the original "marsh loss" in Jamaica Bay. A NYSDEC Geographic Information System (GIS) Coordinator quantified loss of Jamaica Bay marshes at an average of 60 acres per year since 1951, and they noted that the rate of loss was increasing [104, 105].

The NPS response at the time was to note that "marsh loss is a natural phenomenon" and evident along the entire Atlantic seashore as well as in many other coastal areas of the world. In the state of Louisiana's Lake Pontchartrain estuarine lagoon ecosystem, for example, three football field size marshes are lost daily (a sea level rise of approximately $10 \mathrm{~mm} /$ year), contributing to the loss of 111,500 acres of Spartina marsh from 1998-2004 in 
the Gulf of Mexico [105]. Eventually, an effective management strategy was implemented, and in the early 1980's, a restoration plan was adopted, which called for reduced wastewater discharge and reduced development along the Louisiana shore. More than $\$ 300$ million was spent duringa 24 year period, dramatically reversing the "degraded conditions of the Lake Pontchartrain estuary. This success was touted as the paradigm for coastal estuarine restoration [3, 27]. Tragically, in 2005, Hurricane Katrina and a second storm 2 days later eliminated virtually all that had been accomplished by this restoration effort. A similar situation existed in Jamaica Bay during October 2012 when planning for Jamaica Bay restoration came to a halt due to "Superstorm Sandy".

The results of the xenobiotic investigations associated with JABERRT revealed the persistent concern of environmentally significant contaminates remaining in estuarine sediments dispersed throughout the Jamaica Bay benthic region. These compounds attributed to hazardous material identified in the two closed sanctuary landfills (PAL/FAL) that continue to leak contaminants into Jamaica Bay $[4,90]$. Additional dredging or filling activities in Jamaica Bay have potential to disturb the relatively stable benthic conditions, re-suspend buried contaminants, and redistribute them bay-wide.

\subsection{Jamaica Bay Fisheries and Their Habitat}

The American Fisheries Society (AFS) has recommended close scrutiny of marine fish and invertebrate stocks that may be at risk of declining. AFS also recognizes that Fishery Management Plans (FMPs), which enable the identification of at-risk fish populations, may be the most effective tool for protecting marine species. Jamaica Bay is a finfish nursery and has extensive benthic communities of invertebrates that support juvenile finfish growth and development [30, 37, 62, 106-109].

From 1999 to 2000, the number of fisheries' stocks for which harvest rates exceeded over-fishing rose from 159 to 2,310 over fished stocks. Over-fished stocks rose from 64 to 92 over fished stocks in 2000 alone [62]. Five stocks were "approaching an over fished condition", the same number as in 1999. Over-fishing occurred for 47 major stocks and 35 minor stocks. The spiny dogfish and weakfish, (Squalus acanthis and Cynoscion regalis, respectively) two species identified as over-fished, occur in Jamaica Bay. Some species found in the bay, such as winter flounder (Pleuronectes americanus), while not classified as over-fished, have not been rebuilt to levels that would produce a maximum sustainable yield. Landings and abundance of winter flounder have been declining since 1960 due to the effects of commercial harvesting. However, in Jamaica Bay, winter flounder has been sustainable and increasing. This sustainability may be attributable to Jamaica Bay being a nursery habitat for winter flounder [110]. There is a need for research in Jamaica Bay regarding estuarine fishery production and harvest, particularly with regard to the effect that habitat loss and restored estuarine resources may have on this yield.

Recruitment irregularity is high for estuarine fisheries because of the changeable nature of estuarine fish groups [65, 111, 112]. Anadromous species have limited ranges or specialized habitats that make them vulnerable to impacts from human activity. It has been noted that long term monitoring is needed to make a distinction between local or seasonal environmental changes and population-level responses in biodiversity [113]. It is crucial that fisheries managers recognize signs of environmental degradation early so that biological diversity can be maintained.

Measurements of biodiversity are crucial to understanding environmental change and predicting the ability to cope with disturbance. Physical parameters for monitoring water quality may not provide for "healthy" conditions needed to establish stock yieldsfor recreational fishing. For example, physical parameters would have little if any impact on 
species fecundity and reproductive success. For example, depressed DO levels in surface and benthic waters would be classified for recreational fishing purposes as "degraded". Fisheries trend data, however, reveals that YOY and juvenile finfish (winter flounder) will continue to feed on amphipod (Ampelesc aabdita) species even in bottom waters with hypoxic conditions as low as $1 \mathrm{mg} \cdot \mathrm{L}^{-1}$ or 2 $\mathrm{mg} \cdot \mathrm{L}^{-1}$. The water quality may be considered as requiring improvement, but biodiversity and survivability of species ephemerally using the habitat is not impacted. The JABERRT fisheries results consistently demonstrated this point.

Understanding reproduction and recruitment is necessary for the successful conservation of fish species [109]. The U.S. Fish and Wildlife Service (USFWS) keeps records of stocks of coastal and anadromous fish and endangered aquatic animals and protects some of the habitats important for these species. Jamaica Bay flounder populations have revealed impacts from xenobiotics, potentially providing long-term survivorship concerns for this population [110]. In the northeast, 23 fish hatcheries work to restore and protect species such as the striped bass, American shad, weakfish and winter flounder. The JABERRT study revealed that Jamaica Bay was a significant nursery ground for several game fish andcontinues to support the maintenance of an offshore fishery that requires added protection.

\subsection{General Eco-health of Jamaica Bay}

"Degraded", "capable of restoration", "sustainability" and "reduced resource value" are all emblematic terms used to create a definition for urban stressed estuaries, and no definition has been fully established [101]. Spanning the last three decades, proposals to "restore" Jamaica Bay have all been justified by using pre-existing agency mandates for programs to "dispose of dredged material" masquerading as science-based ecosystem management. The most disturbing aspect of the
Jamaica Bay story is that existing "research" and statistical "inventory and monitoring" trends never justified any of the major actions (i.e. filling in Grassy Bay or re-contouring Jamaica Bay) historically proposed forrestoration of this ecosystem. It seems likely that the naturally functioning ecosystem would have enough restorative function if specific xenobiotic and other pollutant loads (i.e. nitrogen) were removed $[3,114]$. The strategic trade-off to restoring areas that are defined as "degraded" or "impacted" is a process that should be based on proposed "use" values, that may be generic across any estuary (waters that are "fishable" or "swimmable" etc.), but tailored for a system's restoration [21, 103, 115]. Without long-term detailed inventory and ecological trend investigations, a lack of ability to quantify services from estuarine ecosystems management will continue to foster decisions that are not ecologically viable and fail to achieve true ecosystem assessment [116].

\section{Conclusions}

For Jamaica Bay, unsubstantiated data have been used to advance mandates and justify actions for political expediency and economic gain rather than for the effectiveness of ecosystem restoration and preservation. The definition of "degraded" has come to depend more on the societal goals rather than ecological conditions. Productivity, biodiversity and habitat stability in Jamaica Bay have all been shown to be robust. A previously conducted natural resource damages investigation had identified more than 4,652 acres of intertidal salt marsh as "degraded". These habitat types were to be the primary focus of the restoration efforts. This degradation myth has been perpetuated via improper investigation and political influences over "multi-use plans", coastal development scenarios and agency agendas. There has never been a structured, routine and long-term monitoring program for Jamaica Bay, which is essential to contribute the data necessary for effective coastal zone management $[27,34,117]$. 
Restoration of urban ecosystem diversity and resiliency requires an understanding of how natural systems "restore" themselves when rebounding from chronic (measured in decades), low level "impacts" of increasing human influences. "Corrective actions" need to be influenced by long-term monitoring and inventorying of biogeochemical aspects of the functioning ecosystem. Even after the results of the JABERRT study were provided to all regulatory agencies, the NY/NJ Port Authority had, as recently as 2011, proposed to fill in a significant portion of degraded Grassy Bay, and in 2014, to expand a JFK runway extension into Jamaica Bay proper. Public outcry and a revealing of the JABERRT project results prompted a tabling of this proposal for the immediate future.

The Western bays of Nassau County, just 20 miles east of Jamaica Bay have similar physiographic characteristics, and are presently being investigated with a focus on future "restoration" efforts. These goals were defined without regard to hydrologic alterations that have occurred during decades of urbanization and anthropogenic coastal changes (specifically in sediments). As a result, these waterbodies may be a superficial level of ecosystem investigation that does not account for the natural processes already known to be important in the Jamaica Bay ecosystem, immediately to the West.

The results of the JABERRT investigations illuminate the long-held myths about the health and natural functioning of Jamaica Bay and hamper the study of the urban estuarine ecosystem. Fifteen years after the completion of JABERRT, its results and conclusions have not been integrated into the coastal environmental planning processes of New York. Subaqueous borrow pits are still targeted. Airport runways are proposed to be extended, and waste elimination to restore coastal estuarine habitats is lacking. Decades old myths about the natural functioning of Jamaica Bay, dispelled by the JABERRT work, continue to persist. The myth of
Jamaica Bay flushing "very slowly", thus retaining contaminants and nutrients for over 30 days was shown to be inaccurate by several hydrological dye studies conducted by LDEO. They revealed that only 7 days to 10 days is required to flush out the peripheral channels of Jamaica Bay, causing such a significant hydraulic draw and current through the Rockaway Inlet that during daily tidal exchanges no sediment or fine grains can appreciably accumulate in the shallow water of Jamaica Bay to support saltmarsh growth. As recently as 2014, the USACE and the National Park Service, updating the master plan for the Jamaica Bay Wildlife Refuge, continued to promote the idea that the bay is characterized bya "sluggish tidal prism", "degraded water quality" and marsh loss requiring potential "re-contouring" of benthic habitat.

The myth that Jamaica Bay is totally eutrophic and causes anoxia in the bay during summer stratification has been grossly exaggerated, with less than a few days per year being hypoxic and only in bottom waters. Based upon JABERRT and 34 years of water quality monitoring data collected by NPS during summer months, it is clear that DO values may occasionally be hypoxic yet rarely become anoxic (0 $\left.\mathrm{mg} \cdot \mathrm{L}^{-1} \mathrm{DO}\right)$. In the last 24 years of this monitoring program, water quality in Jamaica Bay continues to exhibit true resiliency to urban ecosystem challenges in every categorical parameter for a healthy coastal estuarine ecosystem, and in spite of the many contributions of environmental contaminates to Jamaica Bay.

The myth of Jamaica Bay Spartina marsh loss, projected to be declining at a rate of 5 plus acres per yearduring the last three decades, was based on review of aerial photos and navigation charts. This loss-rate, although locally deemed significant, it is considerably less than major marsh losses in such estuarine systems as in the Louisiana Lake Pontchartrain system. Water quality and species diversity indices exhibit robust levels for the Jamaica Bay estuary, even with a 
negative marsh development trend.

Since recent reductions in the 320 million gallons per day of treated wastewater emptying into Jamaica Bay, with the passage of a local law in New York, Jamaica Bay has identified the reduction in nitrogen-loading to Jamaica Bay as a primary goal. Legislation passed in 2011 authorized New York city funding to upgrade STPs around Jamaica Bay. This effort will go a long way in the future to further improve Jamaica Bay's water quality conditions.

Proposed benthic surface topography re-contouring changes and proposals to fill in sub-aqueous borrow pits as a restoration effort, have been computer modeled with results revealing these efforts to be counter productive in reversing any major causative factor influencing an ecosystem's healthy conditions. The species biodiversity and physical parameter conditions have been shown to be exceptional.

Detailed ecological inventories involving annual monitoring activities spanning decades are critically needed to assist in identifying species, and their respective habitat, being at risk from a panoply of ecosystem stressors [117]. Ecosystem health stressors such as resource harvesting (i.e., removal of horseshoe crabs), invasive species, habitat loss, andintroduction of xenobiotics have all been chronic and long-term, and have accelerated since the beginnings of the Anthropocene [118, 119]. JABERRT type inventories and monitoring networks must be established, especially in National Park Units where the minimum boundaries exist to assist in monitoring, gaining a handle on the level of biodiversity and baseline ecological health or their potential thresholds [120, 121]. In light of coastal impacts associated with the October 2012 Sandy "super storm" to Long Island, a total re-evaluation of ecosystem resilience is in order [122]. It is hopefully anticipated that a newly established City University of New York Consortium, the Science and Resilience Institute of Jamaica Bay will help meet this need.

In summary, the results of the JABERRT studies overwhelmingly indicate:

(1) Water quality and marsh loss: water quality continues to support a robust biological diversity in Jamaica Bay and contributes to "healthy" habitat conditions with extremely limited periods when such parameters as DO levels are so impacted that Jamaica Bay would be dysfunctional or "degraded";

(2) Bio-diversity: Invertebrates, finfish, birds, plant communities and estuarine species show a level of productivity and diversity that rivals much larger coastal ecosystems. The loss of marshes, attributable to hydraulic draw of fine particles that could settle out to create new marsh growth is compensated by marsh growth along the periphery of the head of Jamaica Bay. Marsh islands restoration has been somewhat successful, but long-term monitoring of these efforts will be required;

(3) Xenobiotics: Jamaica Bay has a full complement of xenobiotics stabilized in sediments that should be destabilized by natural phenomena such as coastal storms or by human induced destabilization such as dredging or filling. The ecological significance has yet to be determined. Major emphasis on this topic should occupy future research efforts;

(4) Ecosystem health and attributes of an urban ecosystem Jamaica Bay should be utilized as the ecological resiliency paradigm for determining urbanized "ecosystem health". Urbanization imposes considerable stress on natural systems. However, if natural processes can be unencumbered, restorative processes will be maintained.

It has been shown that this urban estuary, Jamaica Bay in one of the largest of the world's metropolises, ishealthy, ecologicaly, robust and a resilient ecosystem. This manuscript and the original NPS led investigations of the 2000-2001 JABERRT Report, Vol. I-III, should serve as a baseline for evaluating all ecological changes that impact Jamaica Bay, including the effects of Superstorm Sandy, and can be the reference point for subsequent monitoring of ever changing global coastal systems. 


\section{Questioning Ecosystem Assessment and Restoration Practices in a Major Urban Estuary: Perpetuating Myths of Degradation in Spite of the Facts}

\section{Acknowledgements}

This research was possible through funding provided by the U.S. Army Corps of Engineers New York District and the National Park Service Gateway National Recreation Area, Division of National Resources in a Cooperative Agreement N1443 CA-1770-00-003 of 10 March 2000 for JABBERT. The National Park Service Gateway NRA provided funding to the following research scientists, who conducted their respective investigations included here in Jamaica bay as part of their respective JABERRT sub-project. Specific parametric data provided under each monitoring protocol were conducted by the respective research team. Each was led by those noted here. All research conducted under the NPS/C of E Cooperative Agreement was overseen by Dr. John T. Tanacredi as chief of Natural Resources for NPS-GATE NRA from 1978 to 2001, and was included here as provided in the final JABERRT Report. Dr. Arnold Gordon, who led the Columbia University/Lamont Doherty Earth Observatory team of Peteet, D., Lieberman, L., Houghton, R., Huber, B., Rubinstone, J., Takesue, R., Van Green, A., Langdon, C., Sombrotto, R., Bell, R., Carbotte, S., and Flood, R., the National Park Services' Ringenary, M., Frame, G., Kurtzke, C., and Byers, M., Brooklyn Colleges' Franz, D., Hofstra University's Burke, R., the University of Rhode Island-Graduate School of Oceanography's Quinn, J., the National Aeronautics and Space Administration Goddard Center's Gornitz, V., Hartig, E., and Kolker, A., the American Museum of Natural History's Boyko, C., Fordham University's Botton, M., and CUNY, College of Staten Island's Viet, R., all contributed to the NPS/Cof E final JABERRT Report.

Funding from the National Park Service also was provided to the City University of New York, Brooklyn College's Aquatic Research and Environmental Assessment Center (AREAC) and Dowling College Department of Earth \& Marine Sciences, as well as Molloy College's Center for
Environmental Research and Coastal Oceans Monitoring (CERCOM). Riepe, D. (National Park Service, retired) provided staff support. Manuscript preparation by Benneward, P., and Wynne, D. (in memoriam) with finalization by Gorney, R. is greatly appreciated.

All opinions and assessments identified in this manuscript are the principle authors alone, and do not necessarily express such opinions of any individual JABERRT member or associated organization. Any omissions or mistakes are unintentional and the responsibility of the lead author. All reference documents were on file at NPS-GNRA and should be requested from the NPS.

\section{References}

[1] Franz, D. R., and Beatty, H. R. 1988. "Seasonal and Spatial Variability in Macrobenthos Communities in Jamaica Bay, New York-An Urban Estuary.” Estuaries 11 (1): 15-28.

[2] Tanacredi, J. T. 1983. "Coastal Zone Management Practices at an Urban National Park." Environmental Management 7 (2): 143-150.

[3] Tanacredi, J. T. 1987. "Natural Resource Management Policy Constraints and Trade-Offs in an Urban National Recreation Area." In Integrating Man and Nature in the Metropolitan Environment, edited by Adams, L. W., and Leedy, D. L. Chevy Chase, MD: National Institute of Urban Wildlife.

[4] Tanacredi, J. T. 1990. "Fact or Fantasy: From Landfill to National Park." In Environmental Restoration: Science and Strategies for Restoring the Earth, edited by Berger, J. J. Washington, DC: Island Press.

[5] Tanacredi, J. T., Schreibman, M., and Frame, G. W. 2002. Jamaica Bay Ecosystem Research and Restoration Team (JABERRT). Final report.

[6] Tanacredi, J. T., and Badger, C. J. 1995. Gateway: A Visitor's Companion. Mechanicsburg, PA: Stackpole Books.

[7] U.S. National Park Service. 1983. Development Concept Plan and Environmental Assessment: Floyd Bennett Field, Gateway National Recreation Area: New York/New Jersey. Denver, CO: U.S. Department of the Interior, National Park Service, Denver Service Center.

[8] Black, F. R. 1981. Jamaica Bay: A History, Cultural Resource Management Study No. 3. Washington, DC: U.S Department of the Interior, National Park Service, North Atlantic Regional Office. 
[9] McGrath, J. D. C. 1971. "Multidisciplinary Environmental Analysis: Jamaica Bay and Kennedy Airport." Journal of the American Institute of Planners 37: 243-252.

[10] Steimle, J. F. W. 1985. "Biomass and Estimated Productivity of the Benthic Macrofauna in the New York Bight: A Stressed Coastal Area." Estuarine, Coastal and Shelf Science 21: 539-554.

[11] Tanacredi, J. T. 1999. Jamaica Bay JABERRT Protocols Manual. Staten Island, NY: National Parks Service-Gateway Publication.

[12] Tanacredi, J. T., and Schreibman, M. 2001. Jamaica Bay Blue Ribbon Panel on Marsh Loss and Coastal Sea Level Rise: A Future Agenda for Mitigation and Pilot Investigations. Final report.

[13] Gordon, A. L., Bell, R. E., Carbotte, S. M., Flood, R. D., Hartig, E. K., and Kolker, A. S. 2001. Integrated Reconnaissance of the Physical and Biogeochemical Characteristics of Jamaica Bay. New York: Lamon-Doherty Earth Observatory of Columbia University.

[14] Franz, D. R., Aitkin-Ander, B., Borrowski, B., and Friedman, I. 2002. Benthic Macroinvertebrates. Jamaica Bay Ecosystem Research and Restoration Team (JABERRT) Final report (Volume II).

[15] Franz, D. R. 2001. "Recruitment, Survivorship, and Age Structure of a New York Ribbed Mussel Population (Geudensiademissa) in Relation to Shore Level: A Nine Year Study." Estuaries 24 (3): 319-327.

[16] New York State Department of Environmental Conservation. 1985-2000. A Study of the Striped Bass in the Marine District of New York V. Albany, NY: Division of Marine Resources.

[17] Veit, R. R., Bernick, A., and Santora, J. 2001. Birds of the Jamaica Bay Ecosystem. Jamaica Bay Ecosystem Research and Restoration Team (JABERRT) Final report (Volume II).

[18] Cheplick, G. P., and Demetri, H. 1999. "Impact of Saltwater Spray and Sand Deposition on the Coastal Annual Triplasispurpurea (Poaceae).” American Journal of Botany 86: 703-710.

[19] Cheplik, G. P., and Wickstron, V. 1999. "Assessing the Potential for Competition on a Coastal Beach and the Significance of Variable Seed Mass in Triplasispurpurea." Journal of the Torrey Botanical Society 126: 296-306.

[20] McNaughton, S. J. 1968. "Structure and Function in California Grasslands." Ecology 49: 962-972.

[21] Babinchak, J. A., Graikoski, J. T., Dudley, S., and Nitkowski, M. F. 1977. "Distribution of Faecal Coliforms in Bottom Sediments from the New York Bight." Marine Pollution Bulletin 8 (7): 150-153.
[22] Eaton, A. D., and Franson, M. H. 2005. Standard Methods for Water and Wastewater 25th Edition. America: American Public Health Association.

[23] Ringenary, M. 2001-2013. Water Quality Monitoring. Program report.

[24] Schlauch, F. C. 1976. "City Snakes, Suburban Salamanders." Natural History 85: 46-53.

[25] Franz, D. R., and Harris, W. H. 1985. Benthos Study, Jamaica Bay Wildlife Refuge Gateway, National Recreation Area. Final report.

[26] Tanacredi, J. T. 1993. "Is Commercial Shellfish Harvesting Compatible with an Urban National Wildlife Refuge?" Fresenius Environmental Bulletin 2: 174-178.

[27] Tanacredi, J. T., and Loret, J. 1998. Ocean Pulse: A Critical Diagnosis. New York, NY: Plenum Press.

[28] Riebesell, U., Wolf-Gladrow, D. A., and Smetacek, V. 1993. "Carbon Dioxide Limitation of Marine Phytoplankton Growth Rates." Nature 361: 249-251.

[29] Franz, D. R. 1996. "Size and Age at First Reproduction of the Ribbed Mussel Geukensiademissa (Dillwyn) in Relation to Shore Level in a New York Salt Marsh." Journal of Experimental Marine Biology and Ecology 205: 1-13.

[30] Franz, D. R. 1997. "Resource Allocation in the Intertidal Salt-Marsh Mussel Geukensiademissa in Relation to Shore Level." Estuaries 20: 134-148.

[31] Orth, R. J., Heck Jr., K. L., and Diaz, R. J. 1991. "Littoral and Intertidal Systems of the Mid-Atlantic Coast of the United States." In Ecosystems of the World: Intertidal and Littoral Ecosystems, No 24. edited by Mathieson, A. C., and Nienhuis, P. H. The Netherlands: Elsevier.

[32] Mallin, M. A., Burkholder, J. M., Sullivan, M. J., Schaaf, W. E., and Peters, D. S. 1992. "Contributions of Benthic Microalgae to Coastal Fishery Yield." Transactions of the American Fisheries Society 121 (5): 691-695.

[33] Reilly Jr., F. J., Spagnolo, R. J., and Ambrogio, E. 1996. "Marine and Estuarine Shallow Water Science and Management: The Interrelationship among Habitats and Their Management.” Estuaries 22: 731-734.

[34] Tanacredi, J. T. 2001. Limulus in the Limelight, a Species 350 Million Years in the Making and in Peril? New York: Kluwer Academic Publishers.

[35] Tanacredi, J. T., Botton, M. L., and Smith, D. R. 2009. Biology and Conservation of Horseshoe Crabs. New York: Springer Science and Business Media Llc..

[36] Whitlatch, R. B. 1982. The Ecology of the New England Tidal Flats: A Community Profile. Washington, DC: U.S. Fish and Wildlife Service, Biological Services Program.

[37] Franz, D. R. 1982. “An Historical Perspective on 


\section{Questioning Ecosystem Assessment and Restoration Practices in a Major Urban Estuary: Perpetuating 105 Myths of Degradation in Spite of the Facts}

Mollusks in Lower New York Harbor, with Emphasis on Oysters." In Ecological Stress and the New York Bight: Science and Management, edited by Meyer, G. F. Columbia, SC: Estuarine Research Federation.

[38] Pearcy, W. G. 1962. "Ecology of an Estuarine Population of Winter Flounder, Pseudopleuronectes americanus (Walbaum) IV, Food Habitats of Larvae and Juveniles.” Bulletin Bingham Oceanographic Collection 18: 65-78.

[39] Erwin, R. M. 1996. "Dependence of Water Birds and Shorebirds on Shallow-Water Habitats in the Mid-Atlantic Coastal Region: An Ecological Profile and Management Recommendations." Estuaries 19: 213-219.

[40] Botton, M. L., Loveland, R. E., and Jacobsen, T. R. 1994. "Site Selection by Migratory Shorebirds in Delaware Bay, and Its Relationship to Beach Characteristics and Abundance of Horseshoe Crab (Limulus polyphemus) Eggs.” The Auk 111 (3): 605-616.

[41] Franz, D. R., and Harris, W. H. 1985. Gateway National Recreation Area. Division of Natural Resources Report Contract.

[42] Scaglione, A. 1991. Jamaica Bay Fisheries Survey 1985-1986, 1988-1989. Brooklyn, NY: U.S. Department of the Interior, National Park Service, Division of Natural Resources and Compliance.

[43] Franz, D. R., and Harris, W. H. 1985. Benthos Study: Jamaica Bay 1981-1985. US: DOI Contract CX160-1-0031, NPS-GATE.

[44] Franz, D. R. 1993. "Allometry of Shell and Body Weight in Relation to Shore Level in the Intertidal Bivalve Geukensia demissa (Bivalvia: Mytilidae)." Journal of Experimental Marine Biology and Ecology 174 (2): 193-207.

[45] Borowsky, B., Aitken-Ander, P., and Tanacredi, J. T. 1993. "The Effects of Low Doses of Waste Crankcase Oil on Melitanitida Smith (Crustacea: Amphipoda)." Journal of Experimental Marine Biology and Ecology 166 (1): 39-46.

[46] Borowsky, B., Aitken-Ander, P., and Tanacredi, J. T. 1997. "Changes in Reproductive Morphology and Physiology Observed in the Amphipod Crustacean, Melitanitida Smith, Maintained in the Laboratory on Polluted Estuarine Sediments." Journal of Experimental Marine Biology and Ecology 214: 85-95.

[47] Franz, D. R. 1989. "Population Density and Demography of a Fouling Community Amphipod." Journal of Experimental Marine Biology and Ecology 125: 117-136.

[48] Choina, T. 1995. "Invertebrate Production in an Urban Estuary." Masters thesis, Brooklyn College CUNY.

[49] Franz, D. R., Choina, T., and Tanacredi, J. T. 1994.
Jamaica Bay Sand Flats-Species Composition and Diversity. New York, NY: U.S. Department of the Interior, National Park Services, Gateway National Recreation Area.

[50] Borowsky, B. 1980. "Reproductive Patterns of Three Intertidal Salt-Marsh Gammaridean Amphipods.” Marine Biology 55: 327-334.

[51] Borowsky, B. 1980. "The Pattern of Tube-Sharing in Microdeutopis gryllotalpa (Crustacea: Amphipoda)." Animal Behavior 28: 790-797.

[52] Borowsky, B. 1980. "Factors that Affect Juvenile Emergence in Gammarus palustris (Bousfield, 1969)." Journal of Experimental Marine Biology and Ecology 42: 213-223.

[53] Borowsky, B. 1983. "Placement of Eggs in Their Brood Pouches by Females of the Amphipod Crustacea Gammarus palustris and Gammarus mucronatus." Marine Behaviour and Physiology 9: 319-325.

[54] Borowsky, B. 1983. "Reproductive Behavior of Three Tube-Building Peracarid Crustaceans: The Amphipods Jassa falcata and Amphithoevalida and the Tanaid Tanai scavolinii." Marine Biology 77: 257-263.

[55] Borowsky, B. 1987. "The Effects of Embryos of Different Developmental Stages on Reproductive Behavior and Physiology in Brooding Females of the Amphipod Crustacean Gammarus palustris." The Biological Bulletin 172 (2): 155-160.

[56] Borowsky, B. 1987. "Laboratory Studies of the Pattern of Reproduction of the Isopod Crustacean Idotea baltica." Fishery Bulletin 85 (2): 377-380.

[57] Borowsky, B., and Aitken, P. 1991. "Sexually Dimorphic Free Swimming Behaviour in the Amphipod Crustacean Ampelisca abdita." Journal of the Marine Biological Association of the United Kingdom 71: 655-663.

[58] Franz, D. R., and Tanacredi, J. T. 1992. "Secondary Production of the Amphipod Ampelisca abdita Mills and Its Importance in the Diet of Juvenile Winter Flounder (Pleuronectes americanus) in Jamaica Bay, New York." Estuaries 15 (2): 193-203.

[59] Franz, D. R., and Tanacredi, J. T. 1993. "Variability in Growth and Age Structure among Populations of Ribbed Mussels, Guekensia demissa (Dillwyn) (Bivalvia: Mytilidae), in Jamaica Bay, New York (Gateway NRA)." The Veliger 36 (3): 220-227.

[60] Nielsen, K. J., and Franz, D. R. 1995. "The Influence of Adult Conspecifics and Shore Level on Recruitment of the Ribbed Mussel Geukensia demissa (Dillwyn)." Journal of Experimental Marine Biology and Ecology 188: 89-98.

[61] National Marine Fisheries Service, NOAA. 1997. A Study of the Striped Bass in the Marine District of New 
York. VII: 25.

[62] National Marine Fisheries Service. 1998. Status of Fisheries of the United States. Washington, DC: National Oceanic and Atmospheric Administration.

[63] Weinstein, M. P., Litvin, S. Y., Bosely, K. L., Fuller, C. M., and Wainright, S. C. 2000. "The Role of Tidal Salt Marsh as an Energy Source for Marine Transient and Resident Finfishes: A Stable Isotope Approach." Transactions of the American Fisheries Society 129: 797-810.

[64] Richards, R. A., and Rago, P. J. 1999. "A Case History of Effective Fishery Management: Chesapeake Bay Striped Bass." North American Journal of Fisheries Management 19: 356-375.

[65] Able, K. W., and Fahay, M. P. 1998. The First Year in the Life of Estuarine Fishes in the Middle Atlantic Bight. New Brunswick, NJ: Rutgers University Press.

[66] Houde, E. D., and Rutherford, E. S. 1993. "Recent Trends in Estuarine Fishes: Predictions of Fish Production and Yield.” Estuaries 16 (2): 161-176.

[67] Burger, J. 1983. "Jamaica Bay Studies II: Effect of Tidal, Temporal, and Weather Variables on Distribution of Ibises, Egrets and Herons on a Coastal Estuary." Acta Oecologica 4 (3): 289-297.

[68] Morris, A. 1986. "The 1985 Fall Shorebird Season at Jamaica Bay Wildlife Refuge.” The Kingbird 35: 54-72.

[69] Bull, J. 1964. Birds of the New York Area. New York, NY: Harper \& Row.

[70] Bull, J. 1974. Birds of New York State. New York, NY: Doubleday, Natural History Press.

[71] Andrle, R. F., and Carroll, J. R. 1988. The Atlas of Breeding Birds in New York State. Ithaca, NY: Cornell University Press.

[72] Burger, J., and Gochfeld, M. 1983. "Jamaica Bay Studies V: Flocking Associations and Behavior of Shorebirds at an Atlantic Coastal Estuary." Biology of Behaviour 8: 289-318.

[73] Brown, K. M., Erwin, R. M., Richmond, M. E., Buckley, P. A., Tanacredi, J. T., and Avrin, D. 2001. "Managing Birds and Controlling Aircraft in the Kennedy Airport-Jamaica Bay Wildlife Refuge Complex: The Need for Hard Data and Soft Opinions." Environmental Management 28 (2): 207-224.

[74] Burger, J. 1981. "Movements of Juvenile Herring Gulls Hatched at Jamaica Bay Wildlife Refuge, New York." Journal of Field Ornithology 52: 285-290.

[75] Burger, J. 1988. "Jamaica Bay Studies VII: An Overview of Abiotic Factors Affecting Several Avian Groups." Journal of Coastal Research 7: 193-205.

[76] Tanacredi, J. T. 1990. "Naphthalenes Associated with Treated Wastewater Effluents in an Urban National Refuge.” Bulletin of Environmental Contamination and
Toxicology 44: 246-253.

[77] Long, E. R., MacDonald, D. D., Smith S. L., and Calder, F. D. 1995. "Incidence of Adverse Biological Effects within Ranges of Chemical Concentrations in Marine and Estuarine Sediments." Environmental Management 19: 81-97.

[78] Latimer, J. S., and Quinn, J. G. 1996. "Historical Trends and Current Inputs of Hydrophobic Organic Compounds in an Urban Estuary: The Sedimentary Record." Environmental Science and Technology 30: 623-633.

[79] Varekamp, J. C., Buchholtz, Ten Brink, M. R., Mecray, E. L., and Kreulen, B. 2000. "Mercury in Long Island Sound Sediments." Journal of Coastal Research 16 (3): 613-626.

[80] Stalter, R., Byer, M. D., and Tanacredi, J. T. 1996. "Rare and Endangered Plants at Gateway National Recreation Area: A Case for Protection of Urban Natural Areas." Landscape and Urban Planning 35: 41-51.

[81] Wolfe, D. A., Long, E. R., and Thursby, G. B. 1996. "Sediment Toxicity in the Hudson-Raritan Estuary: Distribution and Correlations with Chemical Contamination." Estuaries 19: 910-912.

[82] Seidemann, D. E. 1991. "Metal Pollution in Sediments of Jamaica Bay, New York, USA-An Urban Estuary." Environmental Management 15 (1): 73-81.

[83] Ramondetta, P. J., and Harris, W. H. 1978. "Heavy Metals Distribution in Jamaica Bay Sediments." Environmental Geology 2: 145-149.

[84] Rugge, C. D., Momah, C., and Ahlert, R. C. 1994. "Geochemical Assessment of Waste Oil Distribution at a Municipal Landfill." Journal of Environmental Science and Health Part A: Environmental Science and Engineering and Toxicology 29 (3): 493-501.

[85] Harris, W. H. 1985. "Surface Water Specific Alkalinity as a Tracer for Landfill Leachate Leakage in Coastal Waters." Northeastern Environmental Science 4 (2): 84 .

[86] Jamaica Bay Environmental Group. 1971. Jamaica and Kennedy Airport: A Multi-disciplinary Environmental Study, Volume II. Washington, DC: National Academy of Sciences/National Academy of Engineering.

[87] Tanacredi, J. T. 1977. "Petroleum Hydrocarbons from Effluents: Detection in Marin Environment." Journal Water Pollution Control Federation 49: 216-226.

[88] Tanacredi, J. T. 1980. "Removal of Waste Petroleum Derived Polynuclear Aromatic Hydrocarbons by Rotating Biological Discs." In Proceedings: First National Symposium on Rotating Biological Contractor Technology, 12-13.

[89] Tanacredi, J. T., and Stainken, D. 1981. Automotive Crankcase Oil: Detection in a Coastal Wetlands Environment. Cincinatti, OH: U.S. Environmental 


\section{Questioning Ecosystem Assessment and Restoration Practices in a Major Urban Estuary: Perpetuating Myths of Degradation in Spite of the Facts}

Protection Agency, Municipal Environmental Research Laboratory, Office of Research and Development.

[90] Dewling, R. T., Seidenberg, I., and Kingery, J. 1970. "Effect of Seasonal Effluent Chlorination on Coliforms in Jamaica Bay." Journal Water Pollution Control Federation 42 (7): 1351-1361.

[91] Franz, D. R., Riepe, D., Scaglione, A., and Tanacredi, J. T. 1990. "Does Secondary Production of the Benthic Amphipod Ampelisca abdita, Support Winter Flounder Nursery in Jamaica Bay?" In The New York Natural History Conference Proceedings Abstracts, 2.

[92] Heyer, W. R., Donnelly, M. A., McDiarmid, R. W., Hayek, L. C., and Foster, M. S. 1994. Measuring and Monitoring Biological Diversity. Washington, DC: Smithsonian Books.

[93] Nixon, S. W., and Oviatt, C. A. 1973. "Analysis of Local Variation in the Standing Crop of Spartina alterniflora." Botanica Marina 16: 103-109.

[94] Steimle, F. W., and Caracciolo-Ward, J. 1989. "A Reassessment of the Status of the Benthic Macrofauna of the Raritan Estuary." Estuaries 12: 145-156.

[95] Tanacredi, J. T. 1988. "Policy Restraints and Trade-Offs in an Urban National Recreation Area." In Managing Public Lands in the Public Interest, edited by Dysart, B. C., and Clawson, M. New York, NY: Praeger.

[96] New York City Department of Environmental Protection. 1999. New York City: 1999 Drinking Water Supply and Quality Report. EPA topic report.

[97] Airola, T. M., and Kosson, D. S. 1989. "Digital Analysis of Hazardous Waste Site Aerial Photographs." Journal Water Pollution Control Federation 61 (2): 180-183.

[98] Metha, A. J. 1990. "Significance of Bay Superelevation in Measurement of Sea Level Change." Journal of Coastal Research 6 (4): 801-813.

[99] U.S. Army Corps of Engineers. 2009. NYD NY/NJ Harbor Estuary. Program report.

[100] Tanacredi, J. T., and Cardenas, R. R. 1991. "Biodepuration of Polynuclear Aromatic Hydrocarbons from a Bivalve Mollusk, Mercenaria mercenaria L.." Environmental Science and Technology 25 (8): 1453-1461.

[101] Valette-Silver, N. J., Bricker, S. B., and Salomons, W. 1993. "Historical Trends in Contamination of Estuarine and Coastal Sediments: An Introduction to the Dedicated Issue." Estuaries 16 (3): 575-576.

[102] Bopp, R. F., Simpson, H. J., Chillrud, S. N., and Robinson, D. W. 1993. "Sediment-Derived Chronologies of Persistent Contaminants in Jamaica Bay, New York." Estuaries 16 (3): 608-616.

[103] Bopp, F. R., Simpson, H. J., Olsen, C. R., and Kostyk, N. 1981. "Polychlorinated Biphenyls in Sediments of the Tidal Hudson River, New York.” Environmental Science and Technology 15 (2): 210-216.

[104] Reed, D. J. 1995. "The Response of Coastal Marshes to Sea-Level Rise: Survival or Submergence?" Earth Surface Processes and Landforms 20: 39-48.

[105] Reed, D. J. 2011. "Presentation Key Note Address." In Jamaica Bay Conference at Brooklyn College CUNY, 2.

[106] National Marine Fisheries Service. 2001. Status of Fisheries of the United States. Washington, DC: National Oceanic and Atmospheric Administration.

[107] National Ocean Survey 1994. NOAA Annual Report.

[108] National Ocean Survey 2000. Trends in Ocean Resources. NOAA, USDOC report.

[109] Mackenzie Jr., C. L. 1990. "History of the Fisheries of Raritan Bay, New York and New Jersey." Marine Fisheries Review 52 (4): 1-45.

[110] Augspurger, T. P., Herman, R. L., Tanacredi, J. T., and Hatfield, J. S. 1994. "Liver Lesions in Winter Flounder (Pseudopleurinectes americanus) from Jamaica Bay, New York; Indications of Environmental Degradation." Estuaries 17 (1): 172-180.

[111] McElroy, A. E., Hice, L. A., Frisk, M. G., Purcell, S. L., Phillips, N. C., and Fast, M. D. 2015. "Spatial Patterns in Markers of Contaminant Exposure, Glucose and Glycogen Metabolism, and Immunological Response in Juvenile Winter Flounder (Pseudopleuronectes americanus)." Comparative Biochemistry and Physiology Part D, Genomics and Proteomics 14: 53-65.

[112] Polgar, T. T., Summers, J. K., Cummins, T. A., Rose, K. A., and Heimbuch, D. G. 1985. "Investigation of Relationships among Pollutant Loadings and Fish Stock Levels in Northeastern Estuaries." Estuaries 8 (2): 125-135.

[113] Pereira, H. M., Ferrier, S., Walters, M., Geller, G. N., Jongman, R. H. G., and Scholes, R. J. et al. 2013. "Essential Biodiversity Variables." Science 339: 277-278.

[114] Cataldo, J. C., Ronan, A. D., Thatcher, M. L., and Ahmad, J. 1987. "Modeling Stratified Flow in Combined Sewer Overflow." Journal of Hydraulic Engineering 113 (2): 207-223.

[115] D’Avanzo, C., and Kremer, J. N. 1994. "Diel Oxygen Dynamics and Anoxic Events in a Eutrophic Estuary of Waquoit Bay, Massachusetts." Estuaries 17: 131-139.

[116] Grabowski, J. H., Brumbaugh, R. D., Conrad, R. F., Keeler, A. G., Opaluch, J. J., and Peterson, C. H., et al. 2012. "Economic Valuation of Ecosystem Services Provided by Oyster Reefs." BioScience 62 (10): 900-909.

[117] Marsh, D. M., and Trenham, P. C. 2008. "Current Trends in Plant and Animal Population Monitoring." Conservation Biology 22 (3): 647-655.

[118] Diamond, J. M., and Veitch, C. R. 1981. "Extinctions 
108 Questioning Ecosystem Assessment and Restoration Practices in a Major Urban Estuary: Perpetuating Myths of Degradation in Spite of the Facts

and Introductions in the New Zealand Avifauna: Cause and Effect?" Science 211: 499-501.

[119] Jackson, J. B. C., Kirby, M. X., Berger, W. H., Bjorndal, K. A., Botsford, L. W., and Bourque, B. J. et al. 2001. "Historical Overfishing and the Recent Collapse of Coastal Ecosystems." Science 203: 629-637.

[120] Dolan, R., Hayden, B. P., and Soucie, G. 1978.
"Environmental Dynamics and Resource Management in the U.S. National Parks." Environmental Management 2 (3): 249-258.

[121] Ray, G. C. 1991. "Coastal-Zone Biodiversity Patterns." Bio. Science 41: 490-498.

[122] Tanacredi, J. T., and Schreibman, M. P. 2016. Personal Communication. 